\title{
Effects of Combined Abiotic Stresses On Nutrient Content of European Wheat and Implications For Nutritional Security Under Climate Change Scenarios
}

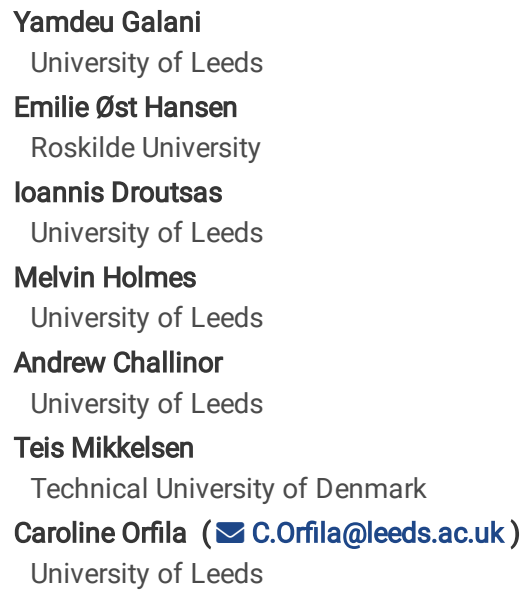

Version of Record: A version of this preprint was published at Scientific Reports on April 5th, 2022. See the published version at https://doi.org/10.1038/s41598-022-09538-6. 


\section{Abstract}

Climate change is causing problems for agriculture, but the effect of combined environmental stresses on crop nutritional quality is not clear. Here we studied the effect of 10 combinations of climatic conditions (temperature, $\mathrm{CO} 2,03$ and drought) in controlled growth chamber conditions on the protein and mineral content of 3 wheat varieties. Results show that wheat plants under 03 exposure alone concentrated $15-31 \%$ more grain N, Fe, Mg, Mn P and $\mathrm{Zn}$, reduced $\mathrm{K}$ by $5 \%$, and $\mathrm{C}$ did not change. Ozone in the presence of elevated $\mathrm{CO} 2$ and higher temperature enhanced the content of Fe, Mn, P and Zn by $2-18 \%$. Water-limited chronic 03 exposure resulted in 9-46\% higher concentrations of all the minerals, except $\mathrm{K}$. The effect of climate change could increase the ability of wheat to meet adult daily dietary requirements by 1.06-1.12-fold for Fe, $\mathrm{Zn}$ and protein, but decrease those of $\mathrm{Mg}, \mathrm{Mn}$ and $\mathrm{P}$ by $1.03-1.06$-fold, and $\mathrm{K}$ by 2.78 -fold. The role of wheat in future nutrition security is discussed.

\section{Main}

Wheat (Triticum aestivum and T. durum) is the third most produced food crop worldwide after maize and rice, with 766 million tons harvested in 2019 , mainly in Asia (44.1\%), Europe (34.8\%) and the Americas (15.3\%). Wheat is key to food and nutrition security of populations worldwide. Average daily supply of wheat and its products is estimated at $179 \mathrm{~g}$ per capita, providing $527 \mathrm{kcal}, 15.8 \mathrm{of} \mathrm{g}$ protein and $2.4 \mathrm{~g}$ of fats. It is consumed in all the continents, Europeans being the largest consumers with $298.6 \mathrm{~g} /$ day, followed by Oceanians, Asians, and Americans. Africans have the lowest consumption of $130.6 \mathrm{~g} / \mathrm{day}{ }^{1}$. Among the world main staples, wheat shows high content of proteins ( 13\%), carbohydrates ( 71\%) and dietary fiber ( 12\%), and comparatively high amount of several minerals, the highest being manganese, selenium, calcium, zinc and copper ${ }^{2}$. Despite the importance of wheat as human food, more than 800 million people are undernourished in the world, and between 1.5 to 2 billion people suffer from one or more chronic micronutrient deficiencies (MNDs), notably deficiencies in calcium, iodine, iron, selenium, zinc, folate and vitamin $\mathrm{A}^{3-6}$. Any change to the nutrient content of wheat can have a large impact on nutrient intake and dietary health of millions of people. To address global food security, sustainable crop production is crucial and requires a suitable input of chemical fertilizers containing macro and micronutrients. However, climatic factors beyond farmers' management capabilities determine the final crop yields. World's climate has been changing more rapidly than ever due to human activities such as industrialization and deforestation, and these changes can dramatically affect crop production and availability of nutrients for human consumption ${ }^{7}$. Water, temperature and $\mathrm{CO}_{2}$ are well-known parameters influencing the growth and development of plants. Another climatic factor, the concentration of ozone $\left(\mathrm{O}_{3}\right)$, can exert synergistic or antagonistic interactions on plant defense mechanism and influence plant growth and yield in various ways ${ }^{8}$.

Individual climate factors can affect wheat production and grain quality in different ways. High temperature treatment $\left(40 / 20\right.$ vs $25 / 20^{\circ} \mathrm{C}$ day/night) ten days after anthesis reduced grain number, weight, and the content of polysaccharides and proteins in many wheat varieties ${ }^{9}$. Elevated concentration of atmospheric $\mathrm{CO}_{2}$ (546-586 ppm) lead to lower concentrations of $\mathrm{Zn}$ and Fe in $\mathrm{C}_{3}$ grains and legumes, and $\mathrm{C}_{3}$ crops other than legumes showed lower concentrations of protein ${ }^{10}$. Högy et al. ${ }^{11}$ observed an increase of 1000-grain weight, but a decrease in proteins, amino acids, Fe and Ca when CO2

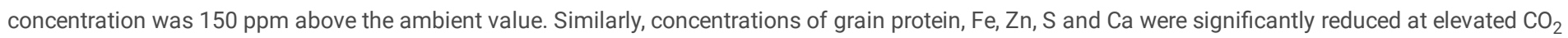
(550 ppm) as compared to the ambient $384 \mathrm{ppm}^{12}$. Chronic elevated $\mathrm{O}_{3}(+25-35 \mathrm{ppb})$ resulted in lower rubisco enzyme activity, chlorophyll and photosynthetic rate in $T$. aestivum wheat, and significantly reduced sugar, starch and protein contents in the two wheat varieties ${ }^{13}$. A review of 42 experiments performed in Asia, Europe and North America showed that high $\mathrm{O}_{3}$ has a strong negative effect on 1000-grain weight, and weaker but significant negative effects on starch concentration and volume weight. Conversely, significant increase of protein and several nutritionally important minerals ( $\mathrm{K}, \mathrm{Mg}$, Ca, $\mathrm{P}, \mathrm{Zn}$, $\mathrm{Mn}, \mathrm{Cu}$ ) was observed, but yields were significantly decreased. For $\mathrm{Fe}, \mathrm{S}$ and $\mathrm{Na}$, effects were not significant or results were inconclusive ${ }^{14}$.

Climate change in the recent decades has led to significant geographical and seasonal redistribution in precipitation and rise in temperature ${ }^{15}$. Water deficit (drought), non-uniform precipitation, and the occurrence of prolonged dry spells, especially when happening in the critical stage of crop development, have a direct effect on the grain yield, physical and nutritional quality of crops worldwide. Therefore, it is necessary to obtain crops that under conditions of low water availability maintain high productive potential without losing their nutritional quality ${ }^{16}$. In wheat, water deficit at grain filling stage reduces grain-filling duration and ultimately reduces grain number and size ${ }^{17}$. Water deficit also reduced grain yield of common bean, triticale and wheat, reduced macro and micronutrient contents in the grains, caused an undesirable change in their physical quality, and altered their chemical quality ${ }^{18}$. Under severe drought conditions, a significant reduction in total protein and carbohydrates and a gradual augmentation in total fibers in wheat grains was observed ${ }^{19}$. Contrarily, moderate drought during grain filling in wheat was found to increase grain protein content, although a slight decrease in grain yield was also observed 20 . However, the outcome of the combined effect of drought with other climate change factors on wheat grain quality is not yet well understood.

Simultaneous combinations of changes in climatic factors may not result in additive effects on plant growth and productivity ${ }^{21-23}$. Wheat cultured under higher temperature and $\mathrm{CO}_{2}$ conditions $\left(700 \mathrm{ppm} \mathrm{CO}\right.$ and $3^{\circ} \mathrm{C}$ temperature rise) had significantly lower straw and grain yield, particularly due to severe reduction in number of spikes per plant, although supplied with ample fertilization ${ }^{7}$. Multifactor combination of ambient or elevated $\mathrm{CO}_{2}(385$ and $700 \mathrm{ppm}$ ), O3 $(20$ and $60 \mathrm{ppb})$ and temperature $\left(19 / 12\right.$ and $\left.24 / 17^{\circ} \mathrm{C}\right)$ showed a decrease in growth and production in oilseed rape and barley ${ }^{21}$. In soybean however, high $\mathrm{CO}_{2}(600 \mathrm{ppm})$ decreased $\mathrm{Fe}$ and $\mathrm{Zn}$ concentration in grains, while combination of high temperature $\left(+3.4 /+2.7^{\circ} \mathrm{C}\right)$ and high $\mathrm{CO}_{2}$ restored the $\mathrm{content}$ of these minerals to levels obtained under ambient $\mathrm{CO}_{2}(400 \mathrm{ppm})$ and canopy temperature conditions ${ }^{24}$. In the opposite, maximum decrease in wheat grain yield (43.6\%) was observed under the additive effect of $50 \%$ water deficit stress and elevated $\mathrm{O}_{3}(+20 \mathrm{ppb})$, while water deficit stress alone reduced grain yield by $19.8 \%$, and elevated $\mathrm{O}_{3}$ alone by $17.9 \%{ }^{25}$. More interestingly, a climate chambers multifactorial experiment with combination of $\mathrm{CO}_{2}(400$ and $700 \mathrm{ppm})$, temperature $\left(19 / 12\right.$ and $\left.24 / 17^{\circ} \mathrm{C}\right)$ and different $\mathrm{O}_{3}$ exposure regimes (5.9 -7.2 ppb and episodic or chronic 80 to $\left.100 \mathrm{ppb}\right)$ on different wheat varieties showed that their growth responses and yields were affected differently by climate factor combinations, and response to temperature change overrode responses to 
changes in $\mathrm{CO}_{2}$ and $\mathrm{O}_{3}{ }^{26}$. These observations underline the complexity of plant response to changes in climatic factors, and therefore, when accessing the effects of future climatic conditions on crops and foods, multiple environmental parameters must be simultaneously considered.

Response to climate change differs not only among crop species ${ }^{10,21,27}$, but also among crop varieties of the same species. Elevated $\mathrm{O}_{3}$ caused higher yield loss in normal maize cultivars than in quality protein maize (QPM) cultivars; carbohydrate content reduced more in normal maize, while essential amino acids and saturated fatty acids showed more decline in QPM ${ }^{28}$. Under elevated $\mathrm{O}_{3}$, more reduction of grain yield was observed in $T$. aestivum (15 and $19 \%$ ) as compared to T. durum (9 and 13\%) ${ }^{13}$. Similarly, the landrace variety of wheat was more sensitive to $\mathrm{O}_{3}$ than the modern varieties ${ }^{26}$. These differences of response between cultivars of a single crop suggest that breeding could partly address the challenges of climate change to crop production ${ }^{10}$, and this implies that different varieties should be assessed when measuring climate change effects on crops.

Without action, climate change will impact nutrition through decreased food quantity and access, decreased dietary diversity, and decreased food nutritional content ${ }^{29,30}$. Modelling studies have investigated how elevated $\mathrm{CO}_{2}$ would impact nutritional quality of staples globally, notably its impact on protein ${ }^{31}, \mathrm{Zn}{ }^{32}$, $\mathrm{Fe}^{33}$, and nutrients in general ${ }^{34}$. Changes in nutrient content of wheat as result of climate change may also influence the amount of wheat to be consumed in order to meet the nutrient needs of populations. In order to obtain a full picture of the threats of climate change to food security, a number of quality effects including yield of protein and important minerals need to be assessed, together with their direct potential adverse effects on malnutrition and health ${ }^{14}$. Moreover, several authors recommended that studies should include interactions of global change parameters that might have strong effects on agriculture such as increase of $\mathrm{O}_{3}$, elevated $\mathrm{CO}_{2}$, rising temperatures and changes in water availability ${ }^{14,27,35,36}$. Very little consideration have been given to interaction of $\mathrm{O}_{3}$ with other abiotic factors on yield and nutrient content of plants. Besides, to our knowledge, no attempts have been made to measure to what extend combined climate change factors will affect food consumption and dietary intake to fulfil the nutritional requirements of the population. Therefore, this study aimed to evaluate the effect of combinations of future climate scenarios (temperature, $\mathrm{CO}_{2}, \mathrm{O}_{3}$ and drought) on nutrient content of 3 spring wheat varieties, and estimate the consequence of changes in nutrient content on wheat contribution to nutrition security in a climate changing world.

\section{Results}

\subsection{Effects of climate parameters on wheat mineral content}

\subsubsection{Carbon}

The $\mathrm{C}$ content of wheat varieties in the controls was between 45.08 and $45.21 \mathrm{~g} / 100 \mathrm{~g} \mathrm{dw}$. Minor significant higher $\mathrm{C}$ content (between $0.47 \%$ and $0.16 \%$ ) were obtained in some temperature treatments, but in general, the climate factors did not considerably affect $\mathrm{C}$ content of wheat varieties. Content of $\mathrm{C}$ in Lantvete was significantly higher than that of Lennox $(p=.028)$, but did not differ from content in KWS Bittern ( $p=.412)$ (Figure 1A, Supplementary table 1 and Supplementary Figure 1).

\subsubsection{Nitrogen, protein and gluten}

The initial $\mathrm{N}$ content of wheat varieties ranged from 1.89 to $1.94 \mathrm{~g} / 100 \mathrm{~g} \mathrm{dw}$. Significantly higher concentrations were recorded in response to all the climate change treatments, in all the wheat varieties, from 3.99-51.92\%. The varieties responded differently to each treatment: the highest $\mathrm{N}$ values in $\mathrm{KWS}$ Bittern (43.37\% and $43.63 \%$ ) were obtained with treatments CT.O3 and T.EpO3, respectively; in Lantvete it was $50.81 \%$ with treatment CT; while in Lennox it was 51.92\% with CT.Ep03. In all the varieties, treatment A.EpO3 lead to the lowest N increase (Figure 1B).

When each climate parameter was considered alone, highest $\mathrm{N}$ values were obtained with chronic $\mathrm{O}_{3}$ treatments, followed by episodic and then normal $\mathrm{O}_{3} ; \mathrm{N}$ content under high $\mathrm{CO}_{2}$ treatments were slightly greater than under ambient $\mathrm{CO}_{2}$; treatments with higher temperature showed higher $\mathrm{N}$ content than those with lower temperature. Under presence of $\mathrm{O}_{3}$ however, high $\mathrm{CO}_{2}$ equally affects $\mathrm{N}$ content irrespective of the $\mathrm{O}_{3}$ regime, while for ambient $\mathrm{CO}_{2}$, $\mathrm{N}$ content is higher with episodic $\mathrm{O}_{3}$, and highest with chronic $\mathrm{O}_{3}$. Similarly, higher temperature has a comparable effect on $\mathrm{N}$ content irrespective of the $\mathrm{O}_{3}$ regime, while the effect of lower temperature is enhanced under episodic $\mathrm{O}_{3}$, and more enhanced under choric $\mathrm{O}_{3}$ (Supplementary Figure 2).

Water-limited treatment with KWS Bittern slightly reduced N content by $2.10-4.57 \%$, when compared to their respective controls. But when compared to the control treatment $(A)$, significant increase $(p<.001)$ of $29.31 \%$ and $40.37 \%$ were obtained for treatments WLA.03 and WLCT.03, respectively (Supplementary Table 1 ).

Overall, for all the control and the treatments, $\mathrm{N}$ content of landrace variety Lantvete was significantly higher than that of modern varieties KWS Bittern $(p=.013)$ and Lennox ( $p=.017)$ (Supplementary Table 1 and Supplementary Figure 2$)$.

Protein content of wheat grains followed the same pattern as $\mathrm{N}$ content, as the former was mathematically derived from the later: it varied from 11.64 to 12.11 $\mathrm{g} / 100 \mathrm{~g} \mathrm{dw}$, all the climate change treatments resulted in significant higher protein content. The content of gluten in wheat grains of the controls was between $22.22 \%$ and $23.40 \%$ proteins. It varied with climate change treatments following the similar trend of protein content.

\subsubsection{Iron}

The initial content of Fe in wheat varieties was between 2.33 and $2.40 \mathrm{mg} / 100 \mathrm{~g} \mathrm{dw}$. Climate change treatments significantly enhanced Fe concentration in grains, by $15.07-78.58 \%$ in Lantvete, $9.31-76.10 \%$ in KWS Bittern, and $18.46-59.50 \%$ in Lennox. A similar pattern was observed in all the varieties: the highest increased was recorded with treatment CT.03 or СT.Ep03, followed by T.EpO3, A.03 and CT; while C.EpO3 and A.EpO3 recorded the lowest Fe increase (Figure 1C). 
Chronic $\mathrm{O}_{3}$ treatments showed highest values of Fe content, followed by episodic $\mathrm{O}_{3}$, and then normal $\mathrm{O}_{3}$. Treatments with high $\mathrm{CO}_{2}$ yielded higher Fe than those with ambient $\mathrm{CO}_{2}$. Higher temperature treatments showed higher Fe contents than treatments at lower temperature. The effect of $\mathrm{CO}_{2}$ was boosted by episodic and chronic $\mathrm{O}_{3}$ exposure, as compared to the normal exposure. Similar observation was recorded on effect of temperature in presence of $\mathrm{O}_{3}$ exposure (Supplementary Figure 3).

When compared to their respective controls, the water-limited treatment did not affect Fe content, but as compared to the control treatment (A), a significant increase $(p<.001)$ of Fe content was obtained with treatment WLA.03 (50.42\%) and WLCT.03 (68.60\%) (Supplementary Table 1).

Landrace variety Lantvete showed significantly higher Fe content than modern varieties KWS Bittern ( $p=.001)$ and Lennox ( $p=.023)($ Supplementary Table 1 and Supplementary Figure 3).

\subsubsection{Potassium}

Potassium content of the control treatments was in the range $525.99-606.84 \mathrm{mg} / 100 \mathrm{~g} \mathrm{dw}$ and significantly decreased by the treatments, in all the 3 varieties, with a reduction of up to $11.29 \%$ in KWS Bittern $(p<.001)$ and $19.87 \%$ in Lennox $(p<.001)$. An increase under some treatments, but non-significant, was

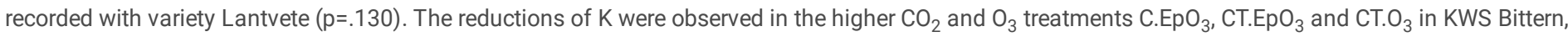
and CT.EpO ${ }_{3}$ in Lennox (Figure 1D).

The different $\mathrm{O}_{3}$ treatments had similar effect on $\mathrm{K}$ content (Figure 4B), and no clear difference could be observed on the effect of the combined treatments on K content.

Except a marginal significant decrease of $8.70 \%(\mathrm{p}=.008)$ obtained with WLA.03 against A.03, K content was not affected by drought treatments (Supplementary Table 1).

On the other hand, K content of Lantvete was significantly lower than that of KWS Bittern $(p=.001)$, but comparable to its content in Lennox ( $p=.131$ ) (Supplementary Table 1 and Supplementary Figure 4).

\subsubsection{Magnesium}

The wheat varieties initially contained $\mathrm{Mg}$ between 109.39 and $141.22 \mathrm{mg} / 100 \mathrm{~g} \mathrm{dw}$. It significantly increased with the climate change treatments, a $23.18-$ $34.03 \%$ increase was recorded in Lantvete, between $8.65 \%$ and $29.71 \%$ in KWS Bittern, and between $18.73 \%$ and $52.46 \%$ in Lennox. Treatment C.EpO3 did not show any significant change of $\mathrm{Mg}$ content in all the three varieties. Except $\mathrm{A} .03$ in KWS Bittern and Lantvete, in general, the highest Mg increases were obtained with the higher temperature treatments CT, СТ.Ер03, СТ.03 and T.EpO3 (Figure 1E).

Magnesium content of treatments with chronic $\mathrm{O}_{3}$ exposure was higher than for treatment with episodic and normal $\mathrm{O}_{3}$. Most of the treatments with high $\mathrm{CO}_{2}$ showed higher $\mathrm{Mg}$ content than treatments with ambient $\mathrm{CO}_{2}$. Higher temperature treatments resulted in $\mathrm{Mg}$ content higher than those of lower temperature. The effect of high $\mathrm{CO}_{2}$ on $\mathrm{Mg}$ content was not affected by any the three $\mathrm{O}_{3}$ exposure regimes, while the effect of ambient $\mathrm{CO}_{2}$ was enhanced by episodic and chronic $\mathrm{O}_{3}$. Similarly, the three $\mathrm{O}_{3}$ regimes did not influence higher temperature effect on $\mathrm{Mg}$ content, but lower temperature showed a stronger effect under chronic $\mathrm{O}_{3}$, followed by episodic, and normal $\mathrm{O}_{3}$ (Supplementary Figure 5).

The water-limited treatments did not affect $\mathrm{Mg}$ content when compared to their respective controls, but when compared to the control treatment $\mathrm{A}$, drought enhanced a significant increase ( $\mathrm{p}<.001$ ) of $\mathrm{Mg}$ content of $13.98 \%$ and $28.45 \%$ for treatments WLA.03 and WLCT.03, respectively (Supplementary Table 1 ).

Overall, the landrace variety Lantvete showed significantly higher Mg content than modern varieties KWS Bittern ( $p<.001)$ and Lennox ( $p=.003)$

(Supplementary Table 1 and Supplementary Figure 5).

\subsubsection{Manganese}

Manganese content of the control treatments was in the range $6.83-7.59 \mathrm{mg} / 100 \mathrm{~g} \mathrm{dw}$. Some climate change treatments resulted in a significant increase of grain Mn by $40.43 \%$ (A.O3) in Lantvete, from 20.98\% (C.EpO3) to $26.21 \%$ (T.EpO3) in Lennox, and 10.91\% (A.EpO3) and 12.68 (A.03) in KWS Bittern. The other treatments resulted in minor non-significantly higher or lower Mn content than in the control A (Figure 1F).

Taken individually, the treatments showing higher values of $\mathrm{Mn}$ content were chronic $\mathrm{O}_{3}$ exposure, followed by episodic $\mathrm{O}_{3}$, and then normal $\mathrm{O}_{3}$, ambient $\mathrm{CO}_{2}$ and lower temperature. Similarly, interaction of episodic $\mathrm{O}_{3}$ exposure with high $\mathrm{CO}_{2}$ or with higher temperature showed no effect, but chronic $\mathrm{O}_{3}$ enhanced higher $\mathrm{Mn}$ content in the presence of ambient $\mathrm{CO}_{2}$ or lower temperature (Supplementary Figure 6).

Treatments with deficiency of water lead to slightly significantly higher Mn contents than those of their respective controls (9.09\% for WLA.03 and $8.54 \%$ for WLCT.03). Comparatively with control A, only treatment WLA.03 resulted in a significant increase of $22.92 \%$ of Mn content (Supplementary Table 1 ).

For all the controls and treatments, Mn content was significantly higher in the landrace variety Lantvete than in the modern varieties KWS Bittern ( $p=.001)$ and Lennox ( $\mathrm{p}=$.037) (Supplementary Table 1 and Supplementary Figure 6).

\subsubsection{Phosphorus}

At baseline, $\mathrm{P}$ content of the wheat varieties varied from 488.84 to $540.63 \mathrm{mg} / 100 \mathrm{~g} \mathrm{dw}$, it significantly increased with the different combination of climate scenarios treatments by $22.99-28.12 \%$ in Lantvete, $10.68-22.54 \%$ in Lennox, and $11.88-20.06 \%$ in KWS Bittern. Treatment A.03 showed the highest P 
content in KWS Bittern Lantvete, while in Lennox, it was treatment CT.03. On the other hand, treatment C.EpO3 did not result in any change of P content in all the varieties (Figure 1G).

Treatments with chronic $\mathrm{O}_{3}$ exposure, followed by episodic $\mathrm{O}_{3}$, and then normal $\mathrm{O}_{3}$, ambient $\mathrm{CO}_{2}$ and higher temperature showed slightly higher values of $\mathrm{P}$ content. While interaction with $\mathrm{O}_{3}$ exposure showed only little effect with high $\mathrm{CO}_{2}$ and higher temperature, higher $\mathrm{P}$ content was obtained under chronic $\mathrm{O}_{3}$ in the presence of ambient $\mathrm{CO}_{2}$ and lower temperature (Supplementary Figure 7).

Submitting the wheat plants to water limitation lead to a significantly $10.85 \%$ lower $\mathrm{P}$ content in grain for treatment WLA.03. As compared to control A, water limitation in combination with chronic $\mathrm{O}_{3}$ exposure resulted in significantly higher P content of $7.13 \%$ and $17.80 \%$, for treatments WLA.03 and WLCT.03, respectively (Supplementary Table 1 ).

In general, $\mathrm{P}$ content was significantly higher in variety Lantvete than in KWS Bittern ( $\mathrm{p}<.001)$ and Lennox ( $<$.001) (Supplementary Table 1 and Supplementary Figure 7).

\subsubsection{Zinc}

The wheat varieties initially contained between 3.70 and $4.05 \mathrm{mg} / 100 \mathrm{~g} \mathrm{dw}$ of $\mathrm{Zn}$, which drastically increased with the climate change treatments. Except treatment A.EpO3 which resulted in a non-significant Zn increase in KWS Bittern and Lantvete, all the other treatment heightened $\mathrm{Zn}$ content of the grains, by 35.35-73.52\% in Lantvete, $18.66 \%$ to 69.29 in Lennox, and $14.24-48.15 \%$ in KWS Bittern. In all the varieties, the greatest $\mathrm{Zn}$ increase was recorded with treatments CT.EpO3 or CT.03, followed by A.03 and T.EpO3 (Figure 1H).

Higher contents of $\mathrm{Zn}$ were obtained with treatments with chronic $\mathrm{O}_{3}$ exposure, followed by episodic $\mathrm{O}_{3}$, and then normal $\mathrm{O}_{3}$, high $\mathrm{CO}_{2}$ and higher temperature. When combined, the two $\mathrm{CO}_{2}$ treatments and the two temperature treatments were influenced by $\mathrm{O}_{3}$ exposure: higher $\mathrm{Zn}$ content were obtained under chronic $\mathrm{O}_{3}$, followed by episodic $\mathrm{O}_{3}$, and then normal $\mathrm{O}_{3}$ (Supplementary Figure 8).

While the effect of water-limited treatment showed a small (4.86\%) reduction on Zn content, comparison with control A shows that combination of drought with other climate change factor significantly enhanced grain Zn by $46.21-40.95 \%$, for treatments WLA.03 and WLCT.O3, respectively (Supplementary Table 1).

Overall, variety Lantvete showed significantly higher Zn content than KWS Bittern ( $p=.036$ ), but its content of Zn did not significantly differ from that of Lennox (p=.097) (Supplementary Table 1 and Supplementary Figure 8).

\subsection{Effect of ozone}

Ozone is one of the most damaging tropospheric air pollutant affecting plant growth and productivity ${ }^{28,37}$ and tropospheric $\mathrm{O}_{3}$ concentrations have more than doubled since pre-industrial times ${ }^{38}$. Wheat is sensitive to elevated $\mathrm{O}_{3}$ levels, causing differences in grain yields and nutrient content ${ }^{13}$. In this study, treatments with $\mathrm{O}_{3}$ alone did not have any noticeable change on $\mathrm{C}$ content, marginally reduced $\mathrm{K}$ content, but significantly increased the content of $\mathrm{N}$ (mean value for the 3 varieties, treatment A.EpO3 $=7.10 \%$ and treatment A.03 $=33.22 \%)$, Fe (14.52\% and 46.73\%), Mg (12.94\% and 25.24\%), Mn (13.33\% and $24.24 \%), P(9.29 \%$ and $20.85 \%), Z n(11.91 \%$ and $46.39 \%)$, protein ( $21.78 \%$ and $35.59 \%)$, and gluten ( $29.73 \%$ and $51.91 \%)$; chronic $\mathrm{O}_{3}$ increased the content of the nutrients more than episodic $\mathrm{O}_{3}$ (Figure 2).

\subsection{Combined effects of climate change factors}

It is realistic to consider that a combination of climate factors will simultaneously impact plant growth and production, and their combined effect on crop quality needs to be assessed. Interaction of $\mathrm{O}_{3}$ with other abiotic factors on yield and nutrient content of plants has been very little considered. Comparison of treatments that combine elevated $\mathrm{CO}_{2}$ and higher temperature with different $\mathrm{O}_{3}$ regimes in this study (CT vs $\mathrm{CT}$.03 and CT.EpO3) showed that under condition of high $\mathrm{CO}_{2}$ and temperature, $\mathrm{O}_{3}$ could significantly increase grain contents of $\mathrm{Fe}$ (mean value for the 3 varieties, treatment $\mathrm{CT}$.EpO3 $=11.86 \%$ and treatment CT.O3 $=21.32 \%)$, Mn (6.02\% for CT.EpO3), P (3.37\% for CT.O3 and Zn (15.71\% for CT.EpO3 and 20.24\% for CT.O3); the effect on the other minerals was not significant; chronic $\mathrm{O}_{3}$ exposure was more effective than episodic (Figure 3 ). However, the effect of these combined climatic factors is not additive: comparing Figure 2 with Figure 3 , it appears that the effect of $\mathrm{O}_{3}$ on mineral content of wheat is greater in ambient $\mathrm{CO}_{2}$ and lower temperature settings.

\subsection{Yield effect}

Because all the treatments caused decrease of yield ${ }^{26}$, the resultant effect on nutrient yield (mass of grain nutrient per unit area) shows a correction towards significantly lower values, at various extend, depending on the initial content. In average, treatments A.Ep03 and WLA.03 in KWS Bittern (median values of $-10.52 \%$ and $9.89 \%$, respectively) resulted in the highest reduction of nutrient content; in Lantvete, treatment A.Ep03 showed overall $33.84 \%$ reduction of nutrients; and in Lennox, treatment A.03 resulted in 12.01\% reduction (Figures 4A and 4B). As compared to the control, the strongest reductions due to yield were observed with $\mathrm{K}$ and $\mathrm{C}$ (median $=32.08 \%$ and $30.53 \%$, respectively), followed by $\mathrm{Mn}(32.65 \%)$ and $\mathrm{P}(13.12 \%)$. The overall impact of climate treatments on nutrient availability was positive for gluten, Fe, Zn and protein, with an increase of $19.11 \%, 14.42 \%, 7.20 \%$ and $4.60 \%$, respectively, while the decrease of yield counterbalanced the gain in concentration of the other nutrients, resulting in decrease of $\mathrm{K}(32.08 \%), \mathrm{Mn}(21.65 \%), \mathrm{P}(13.12 \%)$, and $\mathrm{Mg}$ (7.66\%) (Figure $4 \mathrm{C})$.

\subsection{Trade-off between grain yield and protein content}


The decline in protein content was significantly higher under future $\mathrm{CO}_{2}$ conditions in comparison with the same plants grown with present-day $\mathrm{CO}_{2}$. Moreover, yield explained a lower percentage of the variance in protein content under high $\mathrm{CO}_{2}$. Hence, factors that are not related to atmospheric $\mathrm{CO}_{2}$, such as genotypic differences between the cultivars may become increasingly important for the determination of protein content under future climate change conditions. Our results indicate that under present-day $\mathrm{CO}_{2}$ level, protein content declines by $1.08 \%$ for $1 \mathrm{t} /$ ha increase in yield, regardless of the treatment (low/high temperature, fully irrigated/water stressed, episodic/chronic exposure to $\mathrm{O}_{3}$ ) or the wheat cultivar exposed (Figure 5).

\subsection{Impact on nutrient intake and food security}

Considering the content of nutrient in the control, the wheat consumption for European adults, and their average requirements (AR) of each nutrient, it was obtained that raw whole flour of the wheat varieties investigated in this study could potentially contribute to $45-52 \%$ of $\mathrm{K}$ needs, $75-95 \%$ for $\mathrm{Zn}$ and proteins, $93-120 \%$ for $\mathrm{Mg}$ and $\mathrm{Fe}, 265-293 \%$ for $\mathrm{P}$, and $633-755 \%$ of Mn daily requirements (Figure 6A).

The different climate change treatments in this study resulted in contrasting effect on the percentage of dietary requirement potentially met by the intake of wheat: treatment A.EpO3 resulted in reduction of contribution to the daily AR of all the seven nutrients while treatments CT, CT.EpO3, CT.03, T.EpO3 resulted in an increase, for the majority of the nutrients (Figure 6B). This effect of the climate change treatments was not significant among the three wheat varieties (Figure 6C). As a consequence, the climate change treatments resulted overall in 1.06- to 1.12-fold increase in raw whole wheat contribution in daily AR of Fe, $\mathrm{Zn}$ and protein, 1.03- to 1.06-fold decrease for Mg, Mn and P, and 2.78-fold decrease for K (Figure 6D).

\section{Discussion}

\subsection{Basal mineral content of wheat varieties}

As compared to published nutrient values for spring wheat, whole flour from the UDSA database (NDB Number:20080) ${ }^{2}$ and of 176 spring wheat genotypes

${ }^{39}$, the values of controls in this study were lower for Fe, higher for $\mathrm{K}, \mathrm{Mn}$ and $\mathrm{P}$, and comparable for $\mathrm{Mg}, \mathrm{Zn}$ and protein. Comparatively to the UK Composition of Foods Integrated Dataset (CoFID) $2021^{40}$, the wheat varieties used in the current study contained 2-3 times more K, Mn, P, Zn and Mg, similar amount of protein, but lower Fe concentration than their counterpart (whole meal wheat flour, Food code: 11-889). The differences can be attributed to intrinsic parameters of the cultivars used in this study, and the different environment in which the wheat was grown. The interaction between genotype and the cultivation environment may play a significant role in the determination of the content and composition of wheat grains. For compounds like minerals and heavy metals, site specific variation are to a higher extent the determining factor, and the total content varies among years ${ }^{41}$.

\subsection{Effect of carbon dioxide}

Current atmospheric $\mathrm{CO}_{2}$ concentration (>411 ppm in 2019) are the highest since the last 800,000 years ${ }^{42}$ and are predicted to increase to 550 ppm by 2050 ${ }^{43}$. Elevated $\mathrm{CO}_{2}$ leads to lower content of $\mathrm{Zn}, \mathrm{Fe}, \mathrm{Ca}, \mathrm{S}, \mathrm{N}$, protein and amino acids in wheat grain and other crop products ${ }^{10-12}$. For instance, a metanalysis showed that wheat grown under elevated $\mathrm{CO}_{2}$ had significantly lower grain content of $\mathrm{Zn}$, Fe and protein by $9.3 \%, 5.1 \%$ and $6.3 \%$, respectively ${ }^{10}$. More recently, it was found also that under elevated $\mathrm{CO}_{2}$, concentrations of proteins, $\mathrm{Zn}$ and $\mathrm{Fe}$ in foliar and edible tissues of $\mathrm{C}_{3}$ crops were reduced by $3-17 \%{ }^{27}$. The mechanism by which high $\mathrm{CO}_{2}$ reduces grain nutrient content is not yet clear. Different hypotheses have been proposed including decreased transpirationdriven mass flow of nitrogen ${ }^{44}$, carbohydrate dilution ${ }^{45}$, slow and reduced remobilization of $\mathrm{N}$ to the grain ${ }^{46}$, slower uptake of nitrogen in roots ${ }^{47}$ and inhibition of photorespiration and malate production ${ }^{48}$. Recent evidence suggest that $\mathrm{CO}_{2}$ increase may have a "fertilization" effect on $\mathrm{C} 3$ crops like wheat by increasing leaf photosynthesis in the absence of drought or elevated temperatures, leading to a decrease in the mineral concentration within the seeds 27.

\subsection{Effect of temperature}

Since 1990, land surface temperature has increased by approx. $1^{\circ} \mathrm{C}$ due to anthropogenic increases in $\mathrm{CO}_{2}$ and other greenhouse gases, and by the end of the century, it is projected that global mean surface temperatures will further increase by $2 \cdot 6-4 \cdot 8^{\circ} \mathrm{C}{ }^{42}$. Heat stress can affect wheat growth at any developmental stage, and it has a greater impact on grain yields and grain quality when the stress happens at the reproductive stage ${ }^{9,49}$. Post-anthesis heat stress $\left(35^{\circ} \mathrm{C}\right)$ shortened the grain-filling duration and limited the allocation of resources to grains, leading to lower productivity by $6-51 \%$ in wheat plants grown in controlled environments and by $2-27 \%$ in plants grown under field conditions ${ }^{50}$. The mechanism underpinning these effect of heat stress are linked to its negative effects on floret initiation, including floral abnormalities (i.e. pistil hyperplasia and stamen hypoplasia) and pollen viability (i.e. microspore formation and pollen tube germination), leading to poor fertilization and reduced grain numbers ${ }^{51,52}$. Moreover, under heat stress, leaf senescence and photorespiration are accelerated, rubisco activity is reduced, photosystem II efficiency is disrupted, activities of starch-synthesizing enzyme are inhibited, reactive oxygen species are produced and their excessive level impair many cellular functions: all these result in reduction of the amounts of newly synthesized or stored assimilates that are translocated into developing grains ${ }^{49}$.

\subsection{Effect of ozone}

Our results on Figure 2 partially agree with other reports: elevated $\mathrm{O}_{3}$ resulted in either reduced yield, sugar, starch and protein ${ }^{13}$ or increase in $\mathrm{K}, \mathrm{Mg}, \mathrm{Ca}, \mathrm{P}, \mathrm{Zn}$, $\mathrm{Mn}$ and $\mathrm{Cu}$, and no effect on $\mathrm{Fe}, \mathrm{S}$ and $\mathrm{Na}^{14}$. In maize, chronic $\mathrm{O}_{3}$ exposure decreased the content of grain $\mathrm{P}, \mathrm{Na}, \mathrm{K}$, and increased $\mathrm{Ca}, \mathrm{Mg}, \mathrm{Fe}$, and $\mathrm{Cu}{ }^{28}$. The disparities can be explained by the high variability of sensitivity to tropospheric ozone among species and cultivars ${ }^{13,53}$. Ozone enters in the plant through the stomata of the underside of the leaf, and most likely reacts with molecules in the cell wall, and due to its strong oxidative property it triggers production of reactive oxygen species (ROS). The ROS damage cellular components, resulting in reduction of photosynthesis and other important physiological functions, acceleration of leaf senescence, and reduction of plant growth, with the consequence of weaker plants and impaired yield attributes ${ }^{54-56}$. On the other hand, 
$\mathrm{O}_{3}$-stressed plants maintain to a larger extent $\mathrm{N}$ uptake while biomass accumulation is reduced, resulting in an increased grain protein content ${ }^{57}$. Furthermore, increase of grain mineral concentration may be attributed to a more important synthesis and accumulation of these minerals, as a non-enzymatic antioxidant defense responses to abiotic stress ${ }^{58}$. This could explain why plants under chronic $\mathrm{O}_{3}$ exposure concentrated more minerals in their grain than the episodic $\mathrm{O}_{3}$-exposed plant. The full molecular and physiological mechanism still needs to be elucidated.

\subsection{Effect of drought}

Climate predictions showed that towards the end of this century there will be a global increase in intensity and/or duration of drought, due to alternations in precipitation patterns and increased surface temperature, resulting in hotter and drier climate conditions ${ }^{42}$. In this study, when compared to their chronic $\mathrm{O}_{3}{ }^{-}$ treated counterparts, the water-limited treatments had no effect on $\mathrm{C}, \mathrm{Fe}, \mathrm{Mg}$, increased $\mathrm{Mn}$, and reduced $\mathrm{N}, \mathrm{K}, \mathrm{P}$ and $\mathrm{Zn}$. On the other hand, when considered against the control treatment, the water-limited treatments under chronic $\mathrm{O}_{3}$ exposure did not change the contents of $\mathrm{C}$ and $\mathrm{K}$, and increased those of $\mathrm{N}$, Fe, $\mathrm{Mg}, \mathrm{P}, \mathrm{Mn}$, and Zn (Figure 1, Supplementary Table 1). This indicates that except for $\mathrm{C}$, the effect of drought stress on wheat minerals is reverted under chronic $\mathrm{O}_{3}$ exposure. Drought alone was reported to reduce protein and micronutrients in wheat ${ }^{18,19}$ and the content of grain $\mathrm{N}, \mathrm{K}, \mathrm{Ca}, \mathrm{Mn}$ and $\mathrm{Zn}$ in maize ${ }^{59}$. The degree of stomatal opening and its impact on plant photosynthesis depends on water status and other factors among which $\mathrm{CO}_{2}$ availability ${ }^{26}$. For adaptation of crops to future climate constraints, selection of cultivars resistant to heat and $\mathrm{O}_{3}$ in association with irrigation have been recommended 60

\subsection{Combined effects of climate change factors}

Our results show that overall, combinations of increased temperature, $\mathrm{CO}_{2}, \mathrm{O}_{3}$, and water deficit did not considerably influence grain $\mathrm{C}$ content of the wheat varieties, increased the concentration of $\mathrm{N}$ (by 33\%), Fe (46\%), Mg (23\%), Mn (9\%), P (16\%), Zn (38\%), protein (34\%) and gluten (50\%), and slightly reduced K content (-2\%) (Figure 4C). Growth responses of wheat were affected differently by climate factor combinations, and change due to high temperature overrode the changes due to $\mathrm{CO}_{2}$ and $\mathrm{O}_{3}{ }^{26}$. Combination of elevated $\mathrm{CO}_{2}$ and high temperature can severely reduce duration of time to complete successive growth stages in wheat ${ }^{7}$. When temperature exceeds the optimum level for growth, the positive effects of elevated $\mathrm{CO}_{2}$ on plant growth will be will reverted, as higher temperatures enhance stomatal closure, resulting in smaller $\mathrm{CO}_{2}$ flux into leaves, and this decreases the level of photosynthesis ${ }^{61}$.

\subsection{Varietal differences}

In this study, except for K where KWS Bittern was dominant, the landrace variety Lantvete outperformed the others in content of all the nutrients, both for initial content and for response to climate treatments. Among organically grown wheat genotypes, landraces recorded higher content than cultivars, for twelve nutritionally important minerals ${ }^{39}$. Lantvete showed grain yield plasticity across climate treatments, indicating a trend of not losing additional yields with the future climate scenario ${ }^{26}$. Varietal diversity in response to elevated $\mathrm{O}_{3}$ has been demonstrated in wheat ${ }^{13,62}$ and maize ${ }^{28}$, and against heat stress in wheat ${ }^{9}$ Genotype and environment play a significant role in the determination of the content and composition of crop products ${ }^{41}$, and on primitive wheat, genotype had a higher impact than location ${ }^{39}$. Variability of wheat cultivar responses to the combined effects of climate change factors is due to either more or less additive intraspecific variations and adaptations or it could be that one of the factors has an overriding influence on the impact of other factors ${ }^{26}$. The variation of reduction of yield under elevated temperature across wheat cultivars in South Africa suggested that global warming impacts may be reduced through the sharing of gene pools among wheat breeding programs ${ }^{63}$. These differences of response between cultivars offer a good opportunity for breeding towards more climate robust crops ${ }^{10}$, and our results suggest that Lantvete can be a good candidate for improved nutrients.

\subsection{Yield effect}

A previous report of meta-analysis of the effects of ozone on wheat quality demonstrated that $\mathrm{O}_{3}$ improved the concentration grain protein and minerals ( $\mathrm{K}$, $\mathrm{Mg}, \mathrm{Ca}, \mathrm{P}, \mathrm{Zn}, \mathrm{Mn}, \mathrm{Cu}$ ), but the total amount per unit area was reduced, due to negative effect on yield ${ }^{14}$. Exposure of wheat cultivars in South Africa to temperatures above $30^{\circ} \mathrm{C}$ reduced wheat yield by $12.5 \%$, and this heat effect was different across wheat cultivars ${ }^{63}$. Combined effect of higher temperature and $\mathrm{CO}_{2}$ was shown to reduce straw and grain yield in wheat ${ }^{7}$, as well as combination of elevated $\mathrm{CO}_{2}, \mathrm{O}_{3}$ and temperature reduced plant growth and yield of, oilseed rape and barley ${ }^{21}$. Important decrease of yield was obtained under the additive effect of water deficit and elevated $\mathrm{O}_{3}{ }^{25}$. The observed pattern of reduced yield and increased mineral concentration under $\mathrm{O}_{3}$ exposure can be due to several factors. On one hand, $\mathrm{O}_{3}$ is responsible for reduction of the duration of plant growth which shortens the period of nutrient uptake from the soil, reduction of root-to-shoot ratio because of reduction of photosynthesis and low amount of photosynthates available for root growth, and decrease of plant growth rate with consequently decreased nutrient uptake. On the other hand, stressed crops will try to maintain nitrogen uptake at the cost of biomass accumulation, resulting in enhanced protein and mineral concentration ${ }^{14,57}$. To sum up, under climate change factors, the quality of wheat grain in term of nutrient concentration was improved, but the amount of protein and minerals accumulated per unit area was reduced, which may have serious implications for food security and human nutrition. Since yield reduction by climate change occurs when there is a need of more food to satisfy the demand of the global growing population to meet the demand of 9.1 billion people by $2050{ }^{64}$, it is important to assess how effect of climate of future decades on what could impact food security.

\subsection{Trade-off between grain yield and protein content}

Average decreases of $1.12 \%$ and $1.2 \%$ respectively in wheat grain protein content for $1 \mathrm{t} /$ ha increase in grain yield were reported in previous studies ${ }^{65,66}$. Our results are in line with the above studies. With regards to modelling the effect of $\mathrm{O}_{3}$ on protein content, a simple statistical relationship between grain yield and protein content may provide an efficient parameterization. Under plant exposure to high $\mathrm{O}_{3}$, the observed increase in protein content is a result of the decrease in grain yield ${ }^{66}$, which is already simulated in some crop models ${ }^{67-69}$. It should be noted, however, that Eichi et al. ${ }^{70}$ found that the relationship between grain protein content and yield for wheat in Australia varies between low and high productivity environments. Hence, the linear regression of Figure 5 may not be extrapolated below or above certain yield levels. Overall, our results agree with previous studies that the negative relationship between grain protein content 
and yield becomes stronger under elevated $\mathrm{CO}_{2}{ }^{71,72}$, and a single linear regression based on yield may become less efficient in predicting protein content of wheat grain.

\subsection{Impact on nutrient intake and food security}

Considering the content of nutrient in the control, the obtained values of contribution to AR are very higher than another report which showed that consuming $160 \mathrm{~g}$ of commercially prepared whole-wheat bread contributes in meeting $36 \%$ of protein and $41 \%$ of minerals adequate intake (Al) of adults Europeans and Americans ${ }^{73}$. Similarly, it was shown that consuming $200 \mathrm{~g} /$ day of whole wheat flour from 321 winter and spring wheat genotypes from the Nordic Gene Bank could meet $76 \%$ Fe needs of an adult German, $72-84 \% \mathrm{Mg}, 78 \% \mathrm{Zn}, 90 \% \mathrm{Mn},>100 \% \mathrm{P}$, and $41 \% \mathrm{~K}{ }^{39}$. The difference with our obtained results can be due not only to the location and environment effect on wheat nutrient content, but also on differences in reference intake values and nutrient losses during processing. In fact, there is an approximate $25 \%$ loss of protein, $90 \%$ loss of $\mathrm{Mn}, 85 \%$ loss of $\mathrm{Zn}$, and $80 \%$ loss of $\mathrm{Mg}, \mathrm{K}$ and $\mathrm{Cu}$ when wheat is milled and refined into flour ${ }^{74}, 1.7-4.6 \%$ loss of $\mathrm{Cu}, \mathrm{Mn}$, Fe and $\mathrm{Zn}$ during 60 -day storage and baking of wheat flour ${ }^{75}$. Intake of certain micronutrients are not met in many European countries: a study on adult nutrient intakes from national dietary surveys of European populations showed that although all countries met the female and male WHO recommended nutrient intakes (RNIs) for Zn, intakes of Fe, I and $\mathrm{K}$ were poorly attained in women ${ }^{76}$. In the future, climate change could exacerbate or mitigate the nutrient availability in a largely consumed food like wheat and severely impact food security.

Given that no country in Europe met the RNI for $\mathrm{K}$ in women and only half of countries met the RNI in some male age groups ${ }^{76}$, the recorded negative effect of climate change factors on $\mathrm{K}$ content in wheat could worsen the situation in future decades, resulting in increased risk of $\mathrm{K}$ deficiency. Between 1.5 to 2 billion people suffer from one or more chronic micronutrient deficiencies worldwide. If the current trajectory of 550 ppm atmospheric $\mathrm{CO}_{2}$ by 2050 is maintained, the decrease of nutrients of $\mathrm{C}_{3}$ crops under elevated $\mathrm{CO}_{2}$ for example, could result in 175 million and 122 million more people to be $\mathrm{Zn}$ and protein deficient, respectively ${ }^{27}$. These observations suggest that there is definitely an urgent need of climate-smart and nutrition-sensitive food systems, that could ensure that adaptation strategies to climate change and other disruptions take nutrition into account ${ }^{29}$.

\section{Conclusion}

We evaluated the interactive effects of future climate scenario including higher temperature, elevated $\mathrm{CO}_{2}$, different regimes of $\mathrm{O}_{3}$, and water deficiency, on mineral content of three spring wheat varieties. We observed that plants under $\mathrm{O}_{3}$ exposure alone concentrated more minerals, except $\mathrm{K}$ that was lower. Combined effect of $\mathrm{O}_{3}$ in the presence of elevated $\mathrm{CO}_{2}$ and higher temperature enhanced the content $\mathrm{Fe}, \mathrm{Mn}, \mathrm{P}$ and $\mathrm{Zn}$. The effect of $\mathrm{O}_{3}$ on mineral content of wheat was greater in ambient $\mathrm{CO}_{2}$ and lower temperature settings, and was more pronounced under chronic $\mathrm{O}_{3}$ exposure. The negative effect of drought stress on wheat minerals was reverted under chronic $\mathrm{O}_{3}$ exposure, resulting in higher concentrations. The landrace variety Lantvete outperformed the others. This study confirmed previous models showing that under elevated $\mathrm{CO}_{2}$, the negative relationship between grain protein content and yield becomes stronger, and demonstrated that a single linear regression based on yield would be less efficient in predicting wheat grain protein content. We analyzed the potential repercussions for food and nutrition security of these effects. Climate change could increase the contribution of wheat in meeting the daily nutrient requirements of $\mathrm{Fe}, \mathrm{Zn}$ and protein, but decrease those of $\mathrm{Mg}, \mathrm{Mn}, \mathrm{P}$ and $\mathrm{K}$. This may aggravate some nutrient deficiencies and hamper the reach of sustainable nutrition goal, or necessitate consumption of higher amount of wheat to reach the demand of some nutrients.

\section{Methods}

\subsection{Plant materials}

Three spring wheat varieties were studied, including two modern varieties (Lennox and KWS Bittern) and one landrace (Sweedish Lantvete). Lennox (SaatenUnion) used in southern France was supplied by Dr. Marie Launay, French National Institute for Agriculture, Food, and Environment (INRAE), Agroclim HDR, France. KWS Bittern used in Denmark was supplied by Danish Agro (Karise, Denmark). The landrace variety (Swedish Lantvete) was available from the Nordic Genetic Resource Center (NordGen), Swedish University of Agricultural Sciences, Alnarp, Sweden. All experiments were carried out according to institutional, national and international biosafety standards.

Their life cycle is between 3 to 4 months. Twelve seeds of each variety tested were sown in $11 \mathrm{~L}$ pots filled with $4 \mathrm{~kg}$ of sphagnum (Pindstrup Substrate No. 4 , Pindstrup Mosebrug A/S, Ryomgaard, Denmark) and thinned to 8 plants after germination, corresponding to 165 plants $/ \mathrm{m}^{2}$. As the sphagnum was nutrient enriched with $10 \mathrm{~g}$ NPK fertilizer (21-3-10, Kemira Denmark A/S), no additional nutrients were added to the pots. Tap water was used for watering. Each variety was represented in each treatment with five pots.

\subsection{Climate chamber}

The experiment was performed in climate chambers that provided a controlled environment and uniform conditions, thus eliminating other potentially interacting parameters. The facility used was the RERAF phytotron (Riso Environmental Risk Assessment Facility, Technical University of Denmark, Riso, Denmark), which consists of six gastight chambers sized $6 \times 4 \times 3 \mathrm{~m}$ (length, width \& height), providing detailed control of temperature, $\mathrm{CO}_{2}$, air humidity, light, and $\mathrm{O}_{3}$ concentration and exposure duration. Details of description of the climate chamber are available in $21,77,78$.

\subsection{Climate change treatments}

Full details of the experimental conditions and treatments are available in Hansen et al. ${ }^{26}$. Climate change treatments were selected among possible combinations of two present and future temperature levels $\left(19 / 12^{\circ} \mathrm{C}\right.$ or $24 / 17^{\circ} \mathrm{C}$, both levels simulating days $(16 \mathrm{~h})$ that are warmer than nights $\left.(8 \mathrm{~h})\right)$, two concentrations of $\mathrm{CO}_{2}$ (400 and $700 \mathrm{ppm}$ ), and one of three $\mathrm{O}_{3}$ regimes (no $\mathrm{O}_{3}$ enrichment, episodic $\mathrm{O}_{3}$ exposure, and full-time $\mathrm{O}_{3}$ exposure). Ozone 
concentrations for the treatments without $\mathrm{O}_{3}$ enrichment was the climate chambers background levels $(5.9 \pm 0.5$ to $7.2 \pm 1.7 \mathrm{ppb})$, which are lower than the outside average $\mathrm{O}_{3}$ concentration near the RERAF phytotron (average of $40.4 \mathrm{ppb}$, and maximum $1 \mathrm{~h}$ concentrations between 70.9 and $86.6 \mathrm{ppb}$ ). For both the episodic and full-time $\mathrm{O}_{3}$ exposure treatments, $\mathrm{O}_{3}$ concentration target was $80-100 \mathrm{ppb}$ during the day ( $16 \mathrm{~h}$ of daytime $\mathrm{O}_{3}$ exposure), and chamber background level equivalent to the no $\mathrm{O}_{3}$ enrichment treatments at night. The full-time $\mathrm{O}_{3}$ exposure treatments started at sowing, while the episodic $\mathrm{O}_{3}$ exposure treatments began when Lennox variety reached Zadoks' developmental stage 31 (ZS31 - first node detectable) and ended when the variety reached stage 69 (ZS69 - anthesis complete) ${ }^{79}$.

Throughout the experiment, relative humidity was maintained at 55/70\% (day/night) for all treatments. To provide appropriate supply of water, plants were watered 3 times a week. All plants received increasingly more water as they grew, the warm treatment plants were, by design and by consumption, given more water than ambient treatment plants. Pots were weighed before and after watering to ensure the same amount of water was accessible in the treatment regardless of the pot's previous consumption. Additionally, a water-limited (WL) treatment was given to 2 selected climate combination treatments of variety KWS Bittern. It consisted of limited water supply in $\mathrm{A} .03$ and CT.03, where the plants were subjected to chronic $\mathrm{O}_{3}$ addition, in different $\mathrm{CO}_{2}$ and temperature conditions. Thus, 10 climate treatment combinations were tested in total and named as follows:

- $\mathrm{A}=$ Ambient $\mathrm{CO}_{2}$, lower temperature settings and no $\mathrm{O}_{3}$ addition (control)

- A.EpO3 $=$ Ambient $\mathrm{CO}_{2}$, lower temperature settings and episodic $\mathrm{O}_{3}$ addition

- $\mathrm{A} .03=$ Ambient $\mathrm{CO}_{2}$, lower temperature settings and chronic $\mathrm{O}_{3}$ addition

- $\mathrm{C} . \mathrm{EpO} 3=$ High $\mathrm{CO}_{2}$, lower temperature settings and episodic $\mathrm{O}_{3}$ addition

- $\mathrm{CT}=\mathrm{High} \mathrm{CO}_{2}$, higher temperature settings, and no $\mathrm{O}_{3}$ addition

- CT.EpO3 $=$ High $\mathrm{CO}_{2}$, higher temperature settings and episodic $\mathrm{O}_{3}$ addition

- СT.03 $=$ High $\mathrm{CO}_{2}$, higher temperature settings and chronic $\mathrm{O}_{3}$ addition

- $\mathrm{T}$.EpO3 $=$ Ambient $\mathrm{CO}_{2}$, higher temperature and episodic $\mathrm{O}_{3}$ addition

- WLA.03: Ambient $\mathrm{CO}_{2}$, lower temperature settings and chronic $\mathrm{O}_{3}$ addition (i.e., A.03), in water-limited condition

- WLCT.03 $=\mathrm{High} \mathrm{CO}_{2}$, higher temperature settings and chronic $\mathrm{O}_{3}$ addition (i.e., CT.03), in water-limited condition.

Process values of treatment parameters such as relative humidity, $\mathrm{CO}_{2}$ concentration, and temperature were logged by a data collection system several times per minute. The $\mathrm{O}_{3}$ concentration was monitored twice every hour. At maturity, with moisture content around 9-13\%, grains were harvested, threshed and winnowed, and the grains from plants of each replicate of treatment was mixed for further analyses.

\subsection{Nutrient analysis}

Grains were pulverized into whole wheat flour using a household blender, $600 \mathrm{mg}$ of flour was weighed in a glass test tube, $3 \mathrm{~mL}$ of $69 \% \mathrm{HNO}_{3}$ (Hiperpur, Panreac, Spain) and $2 \mathrm{~mL}$ of deionized water (Milli-Q, Merck, Spain) were added. The mixture was digested in a microwave (Milestone, Ultrawave, Italy) at $240^{\circ} \mathrm{C}$ and 40 bar for $40 \mathrm{~min}$ at $1500 \mathrm{~W}$, and the digesta was brought to a final volume of $50 \mathrm{~mL}$ with Milli-Q water. Minerals (C,N, F, K, Mg, Mn, P, and Zn) were analyzed using inductively coupled plasma optical emission spectroscopy (ICP-OES). Analysis was performed on a PerkinElmer, Optima 4600 DV ICP-OES analyzer (Waltham, USA). The running parameters were set as follow: plasma flow $15 \mathrm{~L} / \mathrm{min}$, auxiliary flow $0.2 \mathrm{~L} / \mathrm{min}$, nebulizer flow $0.8 \mathrm{~L} / \mathrm{min}$, power $1300 \mathrm{~W}$, reading distance $15 \mathrm{~mm}$, reading position radial (K) and axial (Mg, Mn, Zn, Fe and P), integration time 5-10 s, and number of replicas 3. For quantification, standards (Panreac Química SLU, Spain) were prepared in HNO3-H2O in the same proportion as the samples (matrix matched calibration standards). Wheat standard reference material GBW10011 was used for recovery and limits determination. The detection and quantification validation parameters are summarized in Table 1. Nutrient content was corrected from grain moisture content, determined by using the Association of Analytical Communities (AOAC) Method $991.39{ }^{80}$. Content of $\mathrm{N}$ and $\mathrm{C}$ were expressed in $\mathrm{g} / 100 \mathrm{~g}$ dry weight (dw), while Fe, $\mathrm{K}, \mathrm{Mg}, \mathrm{Mn}, \mathrm{P}$ and $\mathrm{Zn}$ were in mg/100g dw. Gluten content was determined according to the ICC 155 procedure ${ }^{81}$ by the Nordic Seed Laboratory Services, and expressed in percent of protein content. Protein content was obtained by multiplying the nitrogen content by $5.83^{82}$ and expressed in $\mathrm{g} / 100 \mathrm{~g} \mathrm{dw}$.

Table 1 Detection and quantification parameters of wheat minerals by ICP-OES

\begin{tabular}{|lllllll|}
\hline Mineral & $\mathbf{K}$ & $\mathbf{M g}$ & $\mathbf{M n}$ & $\mathbf{Z n}$ & $\mathbf{F e}$ & $\mathbf{P}$ \\
\hline ICP-OES wavelengths $(\mathrm{nm})$ & 766.49 & 285.213 & 257.61 & 206.2 & 238.204 & 213.617 \\
\hline Standard concentration range & $0.5-50$ & $0.5-50$ & $1-100$ & $10-1000$ & $10-1000$ & $1-50$ \\
\hline Standard concentration unit & $\mathrm{mg} / \mathrm{L}$ & $\mathrm{mg} / \mathrm{L}$ & $\mu \mathrm{g} / \mathrm{L}$ & $\mu \mathrm{g} / \mathrm{L}$ & $\mu \mathrm{g} / \mathrm{L}$ & $\mathrm{mg} / \mathrm{L}$ \\
\hline Linearity & 0.9999 & 0.9999 & 1.0000 & 0.9998 & 1.0000 & 0.9995 \\
\hline Recovery (\%) & 93.7 & 99.8 & 74.0 & 96.8 & 65.9 & 68.7 \\
\hline RSD $(\%)$ & 6.4 & 6.5 & 5.9 & 7.6 & 6.1 & 6.2 \\
\hline LOD $(\mathrm{mg} / \mathrm{kg})$ & 0.8111 & 0.0262 & 0.00276 & 0.0514 & 0.00178 & 2.604 \\
\hline LOQ $(\mathrm{mg} / \mathrm{kg})$ & 36.198 & 0.173 & 0.00779 & 0.3098 & 0.2448 & 17.11 \\
\hline
\end{tabular}


To evaluate the overall effect of the treatments on grain nutrients availability, yield data from the experiment were obtained from Hansen et al.: all the treatments resulted in yield reduction, from $14-36 \%$ in KWS Bittern, 26-46\% in Lantvete, and 16-37\% in Lennox ${ }^{26}$. Yield data of each treatment was used to correct the value of content of each nutrient, and the yield-corrected nutrient content were compared with the original ones. The potential repercussions of effect of both climate treatments and yield on food and nutrition security under future climate scenarios was analyzed with a case study of European adults. For this, per capita wheat consumption ( $298.55 \mathrm{~g} /$ day) was obtained from FAO food supply data for Europe ${ }^{1}$. Daily average requirements (AR) of each nutrient were obtained from EFSA Dietary Reference Values for the EU database ${ }^{83}$ for adults ( $\geq 18$ years) males, and females not under any physiological status (pregnant, lactating, menopausal). For Zn, values at high level of phytate intake (LPI=1200 mg/day) were considered. These were combined with the yield-corrected nutrient content to estimate the potential percent contribution of each nutrient to average daily intake of some essential nutrients of adults in Europe.

\subsection{Data analysis}

Climate chamber experiments were performed in triplicate, and each wheat sample was analyzed in triplicate. Data were statistically analyzed using IBM SPSS Statistics v 26. ANOVAs were performed to determine the effect individual and combination of treatment on the content of each nutrient, one-way Dunnett's test with treatment $A$ as control was applied for temperature, $\mathrm{CO}_{2}$ and $\mathrm{O}_{3}$ treatments. For drought experiment, each water-limited (WL) treatment was also compared against its corresponding control, i.e., WLCT.03 vs CT.03 and WLA.03 vs A.03. Additionally, performance of landrace variety Lantvete was compared with that of modern varieties KWS Bittern and Lennox using a 1-tailed pairwise Student's t-test. Similarly, a 1-tailed pairwise Student's t-test was also used to assess the significance of differences between original nutrient contents and yield-corrected nutrient contents. Three levels of significance ( 0.05 , 0.01 and 0.001 ) were considered. The trade-off between grain yield and protein content was quantified using linear regressions of the three cultivars growing under baseline $\mathrm{CO}_{2}(400 \mathrm{ppm})$ and future $\mathrm{CO}_{2}(700 \mathrm{ppm})$ levels; the grain yield data were converted to t/ha ${ }^{69}$. Graphical representations were generated using $\mathrm{R}$ version R-4.0.1 and GraphPad Prism version 9.0.2 for Windows.

\section{Declarations}

\section{Acknowledgments}

This work was implemented as part of the CGIAR Research Program on Climate Change, Agriculture and Food Security (CCAFS), which is carried out with support from the CGIAR Trust Fund and through bi-lateral funding agreements. For details please visit https://ccafs.cgiar.org/donors. The views expressed in this document cannot be taken to reflect the official opinions of these organizations. The experimental data is generated as a part of the Joint Programming Initiative on Agriculture, Food Security and Climate Change (FACCE-JPI) and funded by the FACCE-ERA-NET+ Action: Climate-CAFÉ. Saaten-Union, Danish AGRO and Nordic Genebank kindly provided the spring wheat seeds for the study. The nutritional aspects of the work were funded by the Priestley International Centre for Climate through a PhD studentship to ID and by the UK Research and Innovation Biotechnology and Biological Sciences Research Council (UKRI-BBSRC) as part of the Global Challenges Research Fund project Agricultural and Food-system Resilience: Increasing Capacity and Advising Policy (GCRF-AFRICAP, grant number BB/P027784/1) to YJHG, AC and CO. The authors are thankful to the RIAIDT-USC analytical facilities for mineral analyses.

\section{Author Contributions}

EMØH \& TNM conceptualized the crop study, devised the methodology and performed the crop chamber experiments. CO and AC conceptualized the nutritional aspects of climatic effects. YJHG, MJH \& ID analyzed the data. YJHG \& ID drafted the manuscript. All authors critically reviewed and approved the final manuscript. AC \& TNM ensured the resources and funding for the crop project, $C O$ and AC ensured the resources for the nutritional analysis and modelling work.

\section{Competing Interests statement}

The authors declare no competing interests.

\section{References}

1. FAO. Food and Agriculture Organization of the United Nations. FAOSTAT Database. Rome, Italy. http://www.fao.org/faostat/en/\#home (2021)

2. USDA. United States Department of Agriculture (USDA). National nutrient database for standard reference. https://fdc.nal.usda.gov/ (2021)

3. Kumssa, D. B. et al. Dietary calcium and zinc deficiency risks are decreasing but remain prevalent. Sci. Rep, 5, 1-11 (2015).

4. Bailey, R. L., West, K. P. \& Black, R. E. The epidemiology of global micronutrient deficiencies. Ann. Nutr. Metab, 66, 22-33 (2015).

5. Beal, T., Massiot, E., Arsenault, J. E., Smith, M. R. \& Hijmans, R. J. Global trends in dietary micronutrient supplies and estimated prevalence of inadequate intakes. PLoS One, 12, 1-20 (2017).

6. WHO \& UNICEF. Report of the Fourth Meeting of the WHO-UNICEF Technical Expert Advisory group on nutrition Monitoring (TEAM). https://www.who.int/nutrition/events/2017-team-4thmeeting-report.pdf?ua=1 (2017)

7. Asif, M. et al. Effect of predicted climate change on growth and yield performance of wheat under varied nitrogen and zinc supply. Plant Soil, 434, 231244 (2019).

8. Larsen, K. S. et al. Reduced N cycling in response to elevated CO2, warming, and drought in a Danish heathland: Synthesizing results of the CLIMAITE project after two years of treatments. Glob. Chang. Biol, 17, 1884-1899 (2011). 
9. Tomás, D., Rodrigues, J. C., Viegas, W. \& Silva, M. Assessment of high temperature effects on grain yield and composition in bread wheat commercial varieties. Agronomy, 10, 499 (2020).

10. Myers, S. S. et al. Increasing CO2 threatens human nutrition., 510, 139-142 (2014).

11. Högy, P. et al. Grain quality characteristics of spring wheat (Triticum aestivum) as affected by free-air CO2 enrichment. Environ. Exp. Bot, 88, 11-18 (2013).

12. Fernando, N. et al. Rising atmospheric $\mathrm{CO} 2$ concentration affects mineral nutrient and protein concentration of wheat grain. Food Chem, 133, 1307-1311 (2012).

13. Tomer, R. et al. Impact of Elevated Ozone on Growth, Yield and Nutritional Quality of Two Wheat Species in Northern India. Aerosol Air Qual. Res, 15, 329340 (2015).

14. Broberg, M. C., Feng, Z., Xin, Y. \& Pleijel, H. Ozone effects on wheat grain quality - A summary. Environ. Pollut, 197, 203-213 (2015).

15. IPCC. Climate Change 2021: The Physical Science Basis. Contribution of Working Group I to the Sixth Assessment Report of the Intergovernmental Panel on Climate Change. https://www.ipcc.ch/report/ar6/wg1/downloads/report/IPCC_AR6_WGI_Full_Report.pdf (2021)

16. Alexander, L. V. Global observed long-term changes in temperature and precipitation extremes: A review of progress and limitations in IPCC assessments and beyond. Weather Clim. Extrem, 11, 4-16 (2016).

17. Gooding, M. J., Ellis, R. H., Shewry, P. R. \& Schofield, J. D. Effects of restricted water availability and increased temperature on the grain filling, drying and quality of winter wheat. J. Cereal Sci, 37, 295-309 (2003).

18. Silva, A. et al. Water stress alters physical and chemical quality in grains of common bean, triticale and wheat. Agric. Water Manag, 231, 106023 (2020).

19. Hammad, S. A. R. \& Ali, O. A. M. Physiological and biochemical studies on drought tolerance of wheat plants by application of amino acids and yeast extract. Ann. Agric. Sci, 59, 133-145 (2014).

20. Rezaei, M., Zehtab-Salmasi, S., Najafi, N., Ghassemi-Golezani, K. \& Jalalikamali, M. Effects of water deficit on nutrient content and grain protein of bread wheat genotypes. J Food Agric Env, 8, 535-553 (2010).

21. Clausen, S. K. et al. Effects of Single and Multifactor Treatments with Elevated Temperature, CO2 and Ozone on Oilseed Rape and Barley. J. Agron. Crop Sci, 197, 442-453 (2011).

22. Dieleman, W. I. J. et al. Simple additive effects are rare: A quantitative review of plant biomass and soil process responses to combined manipulations of CO 2 and temperature. Glob. Change Biol, 18, 2681-2693 (2012).

23. Shaw, M. R. et al. Grassland responses to global environmental changes suppressed by elevated C02. Science (80-.), 298, 1987-1990 (2002).

24. Köhler, I. H., Huber, S. C., Bernacchi, C. J. \& Baxter, I. R. Increased temperatures may safeguard the nutritional quality of crops under future elevated CO2 concentrations. Plant J, 97, 872-886 (2019).

25. Ghosh, A., Agrawal, M. \& Agrawal, S. B. Effect of water deficit stress on an Indian wheat cultivar (Triticum aestivum L. HD 2967) under ambient and elevated level of ozone. Sci. Total Environ, 714, 136837 (2020).

26. Hansen, E. M. Ã., Hauggaard-Nielsen, H., Launay, M., Rose, P. \& Mikkelsen, T. N. The impact of ozone exposure, temperature and CO2 on the growth and yield of three spring wheat varieties. Environ. Exp. Bot, 168, 103868-103882 (2019).

27. Leisner, C. P. \& Review Climate change impacts on food security- focus on perennial cropping systems and nutritional value. Plant Sci, 293, 110412 (2020).

28. Singh, A. A., Agrawal, S. B., Shahi, J. P. \& Agrawal, M. Yield and kernel nutritional quality in normal maize and quality protein maize cultivars exposed to ozone. J. Sci. Food Agric, 99, 2205-2214 (2019).

29. Fanzo, J., Davis, C., McLaren, R. \& Choufani, J. The effect of climate change across food systems: Implications for nutrition outcomes. Global Food Security, 18, 12-19 (2018).

30. Tai, A. P. K., Martin, M. V. \& Heald, C. L. Threat to future global food security from climate change and ozone air pollution. Nat. Clim. Chang, 4, $817-821$ (2014).

31. Medek, D. E., Schwartz, J. \& Myers, S. S. Estimated Effects of Future Atmospheric CO2 Concentrations on Protein Intake and the Risk of Protein Deficiency by Country and Region. Environ. Health Perspect, 125, 087002 (2017).

32. Myers, S. S., Wessells, K. R., Kloog, I., Zanobetti, A. \& Schwartz, J. Effect of increased concentrations of atmospheric carbon dioxide on the global threat of zinc deficiency: A modelling study. Lancet Glob. Heal, 3, e639-e645 (2015).

33. Smith, M. R., Golden, C. D. \& Myers, S. S. Potential rise in iron deficiency due to future anthropogenic carbon dioxide emissions. GeoHealth, 1, 248-257 (2017).

34. Smith, M. \& Myers, S. S. Measuring the effects of anthropogenic CO 2 emissions on global nutrient intakes: a modelling analysis., 389, S19 (2017).

35. Challinor, A. J., Ewert, F., Arnold, S., Simelton, E. \& Fraser, E. Crops and climate change: Progress, trends, and challenges in simulating impacts and informing adaptation. J. Exp. Bot, 60, 2775-2789 (2009).

36. Lobell, D. B. \& Gourdji, S. M. The influence of climate change on global crop productivity. Plant Physiol, 160, 1686-1697 (2012).

37. Leisner, C. P. \& Ainsworth, E. A. Quantifying the effects of ozone on plant reproductive growth and development. Glob. Chang. Biol, 18, 606-616 (2012).

38. Volz, A. \& Kley, D. Evaluation of the Montsouris series of ozone measurements made in the nineteenth century., 332, 240-242 (1988).

39. Hussain, A., Larsson, H., Kuktaite, R. \& Johansson, E. Mineral composition of organically grown wheat genotypes: Contribution to daily minerals intake. Int. J. Environ. Res. Public Health, 7, 3442-3456 (2010). 
40. Public Health England. McCance and Widdowson's The Composition of Foods Integrated Dataset 2021.

https://assets.publishing.service.gov.uk/government/uploads/system/uploads/attachment_data/file/971018/McCance_Widdowsons_Composition_of_Fc (2021)

41. Johansson, E. et al. Genotypic and environmental effects on wheat technological and nutritional quality. in Wheat Quality For Improving Processing And Human Health (eds. Igrejas, G., Ikeda, T. M. \& Guzmán, C.)171-204(Springer Nature Switzerland AG, 2020). doi:10.1007/978-3-030-34163-3_8.

42. Stocker, T. F. et al. Intergovernmental Panel on Climate Change. Summary for policymakers. in Climate Change 2013, the Physical Science Basis: Working Group I Contribution to the Fifth Assessment Report of the Intergovernmental Panel on Climate Change vol. 97811070571-1535(Cambridge University Press, 2013)

43. Ciais, P. et al. Carbon and other biogeochemical cycles. in Climate Change 2013 the Physical Science Basis: Working Group I Contribution to the Fifth Assessment Report of the Intergovernmental Panel on Climate Change vol. 9781107057 465-570(2013)

44. Pleijel, H. et al. Effects of elevated carbon dioxide, ozone and water availability on spring wheat growth and yield. Physiol. Plant, 108, 61-70 (2000).

45. Gifford, R. M., Barrett, D. J. \& Lutze, J. L. The effects of elevated [CO2] on the C:N and C:P mass ratios of plant tissues. Plant Soil, 224, 1-14 (2000).

46. Seneweera, S., Makino, A., Mae, T. \& Basra, A. S. Response of rice to $\mathrm{p}(\mathrm{CO} 2)$ enrichment: The relationship between photosynthesis and nitrogen metabolism. J. Crop Improv, 13, 31-53 (2005).

47. Leakey, A. D. B. et al. Elevated CO2 effects on plant carbon, nitrogen, and water relations: Six important lessons from FACE. J. Exp. Bot, 60, $2859-2876$ (2009).

48. Bloom, A. J. et al. CO2 enrichment inhibits shoot nitrate assimilation in C3 but not C4 plants and slows growth under nitrate in C3 plants., $93,355-367$ (2012).

49. Abdelrahman, M., Burritt, D. J., Gupta, A., Tsujimoto, H. \& Tran, L. S. P. Heat stress effects on source-sink relationships and metabolome dynamics in wheat. J. Exp. Bot, 71, 543-554 (2020).

50. Bergkamp, B., Impa, S. M., Asebedo, A. R., Fritz, A. K. \& Jagadish, S. V. K. Prominent winter wheat varieties response to post-flowering heat stress under controlled chambers and field based heat tents. F. Crop. Res, 222, 143-152 (2018).

51. Dwivedi, S. K. et al. Heat stress induced impairment of starch mobilisation regulates pollen viability and grain yield in wheat: Study in Eastern IndoGangetic Plains. F. Crop. Res, 206, 106-114 (2017).

52. Rieu, I., Twell, D. \& Firon, N. Pollen development at high temperature: From acclimation to collapse. Plant Physiol, 173, 1967-1976 (2017).

53. Mishra, A. K., Rai, R. \& Agrawal, S. B. Differential response of dwarf and tall tropical wheat cultivars to elevated ozone with and without carbon dioxide enrichment: Growth, yield and grain quality. F. Crop. Res, 145, 21-32 (2013).

54. Bhatia, A., Tomer, R., Kumar, V., Singh, S. D. \& Pathak, H. Impact of tropospheric ozone on crop growth and productivity - a review. J. Sci. Ind. Res. (India), 71, 97-112 (2012).

55. Fuhrer, J. Ozone risk for crops and pastures in present and future climates., 96, 173-194 (2009).

56. Singh, S. et al. Synergistic action of tropospheric ozone and carbon dioxide on yield and nutritional quality of Indian mustard (Brassica juncea (L.) Czern.). Environ. Monit. Assess, 185, 6517-6529 (2013).

57. Wang, Y. \& Frei, M. Stressed food - The impact of abiotic environmental stresses on crop quality. Agric. Ecosyst. Environ, 141, 271-286 (2011).

58. Zouari, M. et al. Enzymatic antioxidant responses and mineral status in roots and leaves of olive plants subjected to fluoride stress. South African J. Bot, 111, 44-49 (2017).

59. Naeem, M. et al. Foliar calcium spray confers drought stress tolerance in maize via modulation of plant growth, water relations, proline content and hydrogen peroxide activity. Arch. Agron. Soil Sci, 64, 116-131 (2018).

60. Tai, A. P. K. \& Martin, M. V. Impacts of ozone air pollution and temperature extremes on crop yields: Spatial variability, adaptation and implications for future food security. Atmos. Environ, 169, 11-21 (2017).

61. DaMatta, F. M., Grandis, A., Arenque, B. C. \& Buckeridge, M. S. Impacts of climate changes on crop physiology and food quality. Food Res. Int, 43, 18141823 (2010)

62. Pleijel, H., Eriksen, A. B., Danielsson, H., Bondesson, N. \& Selldén, G. Differential ozone sensitivity in an old and a modern Swedish wheat cultivar - Grain yield and quality, leaf chlorophyll and stomatal conductance. Environ. Exp. Bot, 56, 63-71 (2006).

63. Shew, A. M., Tack, J. B., Nalley, L. L. \& Chaminuka, P. Yield reduction under climate warming varies among wheat cultivars in South Africa. Nat. Commun, 11, 4408 (2020).

64. FAO. Feeding the world, eradicating hunger. World Summit on Food Security http://www.fao.org/fileadmin/templates/wsfs/Summit/WSFS_Issues_papers/WSFS_Background_paper_Feeding_the_world.pdf (2009)

65. Bogard, M. et al. Deviation from the grain protein concentration-grain yield negative relationship is highly correlated to post-anthesis $\mathrm{N}$ uptake in winter wheat. J. Exp. Bot, 61, 4303-4312 (2010).

66. Pleijel, H. \& Uddling, J. Yield vs. quality trade-offs for wheat in response to carbon dioxide and ozone. Glob. Chang. Biol, 18, 596-605 (2012).

67. Ewert, F. \& Porter, J. R. Ozone effects on wheat in relation to $\mathrm{CO} 2$ : Modelling short-term and long-term responses of leaf photosynthesis and leaf duration. Glob. Chang. Biol, 6, 735-750 (2000).

68. Guarin, J. R., Kassie, B., Mashaheet, A. M., Burkey, K. \& Asseng, S. Modeling the effects of tropospheric ozone on wheat growth and yield. Eur. J. Agron, 105, 13-23 (2019). 
69. Droutsas, I., Challinor, A. J., Arnold, S. R., Mikkelsen, T. N. \& Hansen, E. M. Ø. A new model of ozone stress in wheat including grain yield loss and plant acclimation to the pollutant. Eur. J. Agron, 120, 126125 (2020).

70. Eichi, V. R. et al. Strengths and weaknesses of national variety trial data for multi-environment analysis: A case study on grain yield and protein content. Agronomy, 10, 753 (2020).

71. Mills, G. et al. Closing the global ozone yield gap: Quantification and cobenefits for multistress tolerance. Glob. Chang. Biol, 24, 4869-4893 (2018).

72. Bloom, A. J., Burger, M., Kimball, B. A. \& Pinter, P. J. Nitrate assimilation is inhibited by elevated CO2 in field-grown wheat. Nat. Clim. Chang, 4, $477-480$ (2014).

73. Weegels, P. L. The Future of Bread in View of its Contribution to Nutrient Intake as a Starchy Staple Food. Plant Foods for Human Nutrition vol. 74 (2019)

74. Oghbaei, M. \& Prakash, J. Effect of primary processing of cereals and legumes on its nutritional quality: A comprehensive review. Cogent Food Agric, 2, 114 (2016).

75. Akhtar, S., Anjum, F. M., Salim-Ur-Rehman \& Sheikh, M. A. Effect of storage and baking on mineral contents of fortified whole wheat flour. J. Food Process. Preserv, 34, 335-349 (2010).

76. Rippin, H., Hutchinson, J., Jewell, J., Breda, J. \& Cade, J. Adult Nutrient Intakes from Current National Dietary Surveys of European Populations. Nutrients, 9, 1288 (2017).

77. Frenck, G., van der Linden, L., Mikkelsen, T. N., Brix, H. \& Jørgensen, R. B. Increased [CO2] does not compensate for negative effects on yield caused by higher temperature and [03] in Brassica napus L. Eur. J. Agron, 35, 127-134 (2011).

78. Ingvordsen, C. H. et al. Significant decrease in yield under future climate conditions: Stability and production of 138 spring barley accessions. Eur. J. Agron, 63, 105-113 (2015).

79. Zadoks, J. C., Chang, T. T. \& Konzak, C. F. A decimal code for the growth stages of cereals. Weed Res, 14, 415-421 (1974).

80. Latimer, G. W. Official Method of Analysis of AOAC International (AOAC International, 2012).

81. ICC. ICC-Standard No 155 Approved 1994. International Association for Cereal Science and Technology. https://www.icc.or.at/publications/iccstandards/standards-overview/155-standard-method (1994)

82. FAO. Food energy-Methods of analysis and conversion factors: Report of a technical workshop, Rome, 2002. FAO Food and Nutrition Paper No. 77. http://www.fao.org/uploads/media/FAO_2003_Food_Energy_02.pdf (2003)

83. EFSA. EFSA Dietary Reference Values for the EU. https://efsa.gitlab.io/multimedia/drvs/index.htm (2021)

\section{Figures}



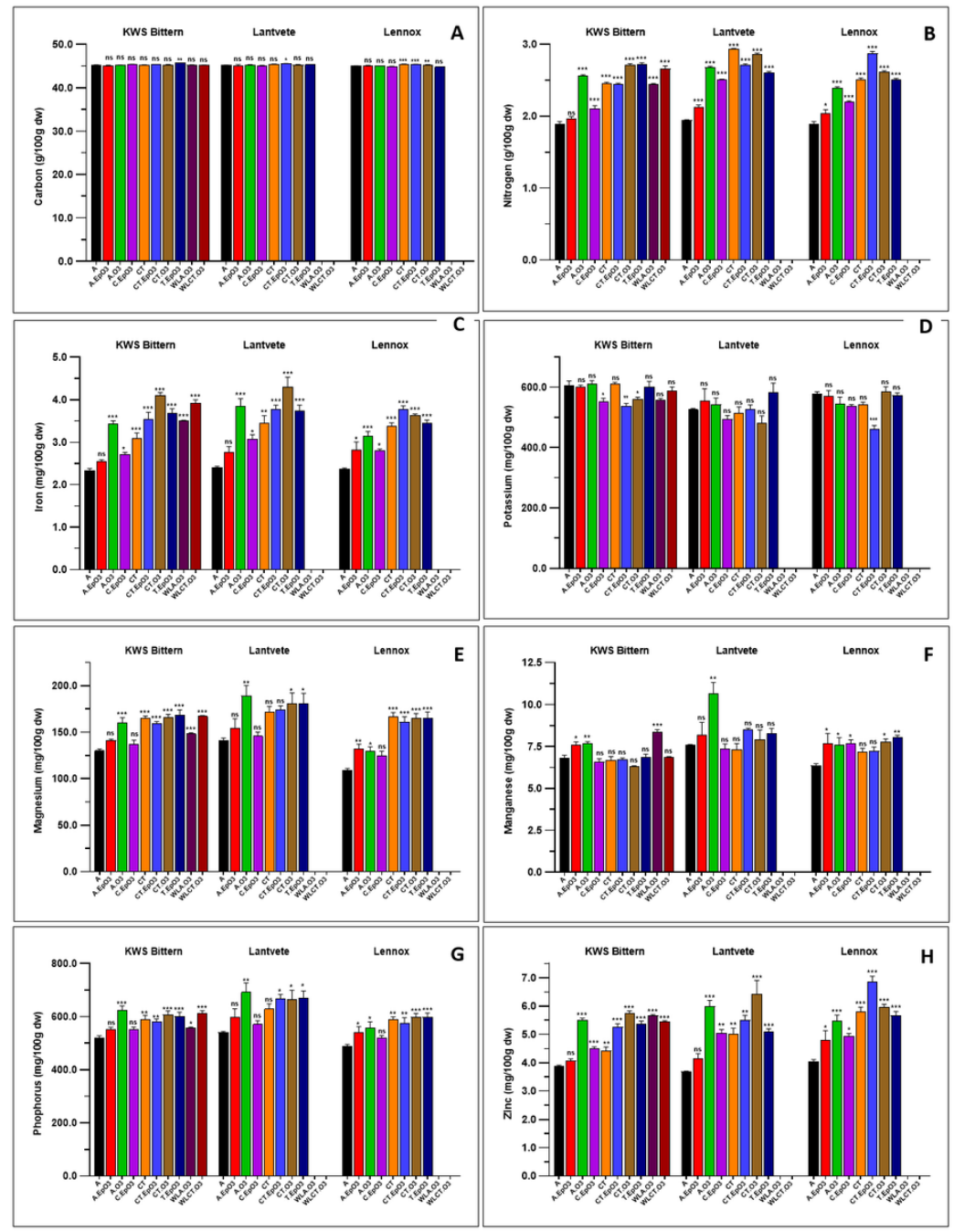

\section{Figure 1}

Effect of temperature, $\mathrm{CO} 2$, ozone and water availability on grain mineral content of wheat. $\mathrm{A}=\mathrm{Ambient} \mathrm{CO} 2$, lower temperature settings and no 03 addition (control). $\mathrm{A} \cdot \mathrm{EpO} 3=$ Ambient $\mathrm{CO} 2$, lower temperature settings and episodic 03 addition. A.03 = Ambient $\mathrm{CO} 2$, lower temperature settings and chronic 03 addition. $\mathrm{C} \cdot \mathrm{EpO} 3=$ High CO2, lower temperature settings and episodic 03 addition. $\mathrm{CT}=$ High $\mathrm{CO} 2$, higher temperature settings, and no 03 addition. $\mathrm{CT}$.EpO3 = High $\mathrm{CO} 2$, higher temperature settings and episodic 03 addition. CT.O3 = High CO2, higher temperature settings and chronic 03 addition. T.EpO3 = Ambient $\mathrm{CO} 2$, higher temperature and episodic 03 addition. WLA.03: Ambient CO2, lower temperature settings and chronic 03 addition (i.e., A.03), in water-limited condition. WLCT.03 = High CO2, higher temperature settings and chronic 03 addition (i.e., CT.O3), in water-limited condition. ns, * ** and *** mean nonsignificant, significant at $0.05,0.01$ and 0.001 , respectively, Dunnett's test with treatment $A$ as control. 


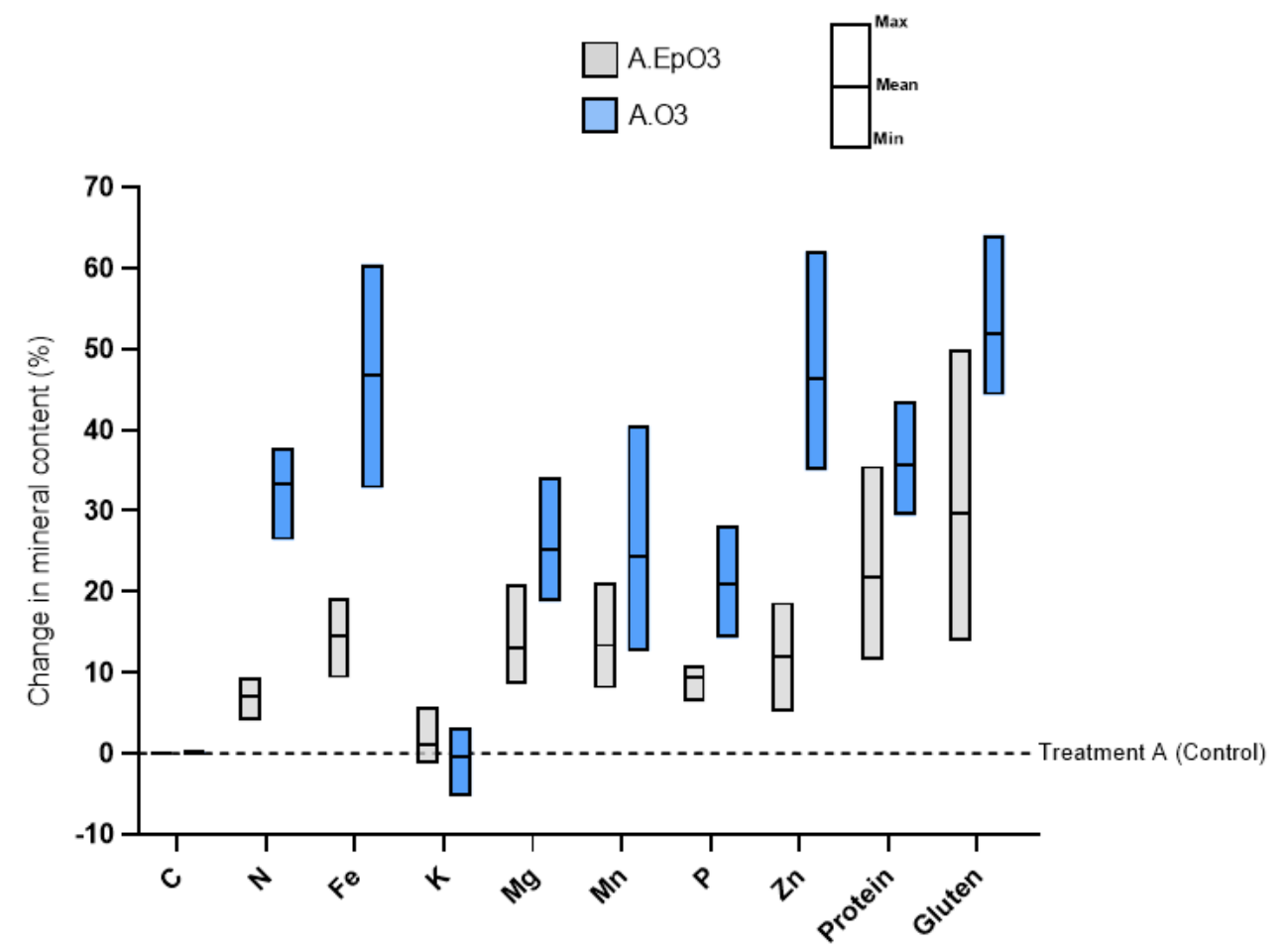

Figure 2

Change of mineral content of three European wheat varieties under effect of ozone. A = Ambient CO2, lower temperature settings and no 03 addition (control). $\mathrm{A} . \mathrm{EpO} 3=$ Ambient CO2, lower temperature settings and episodic 03 addition. $\mathrm{A} .03$ = Ambient $\mathrm{CO} 2$, lower temperature settings and chronic 03 addition.
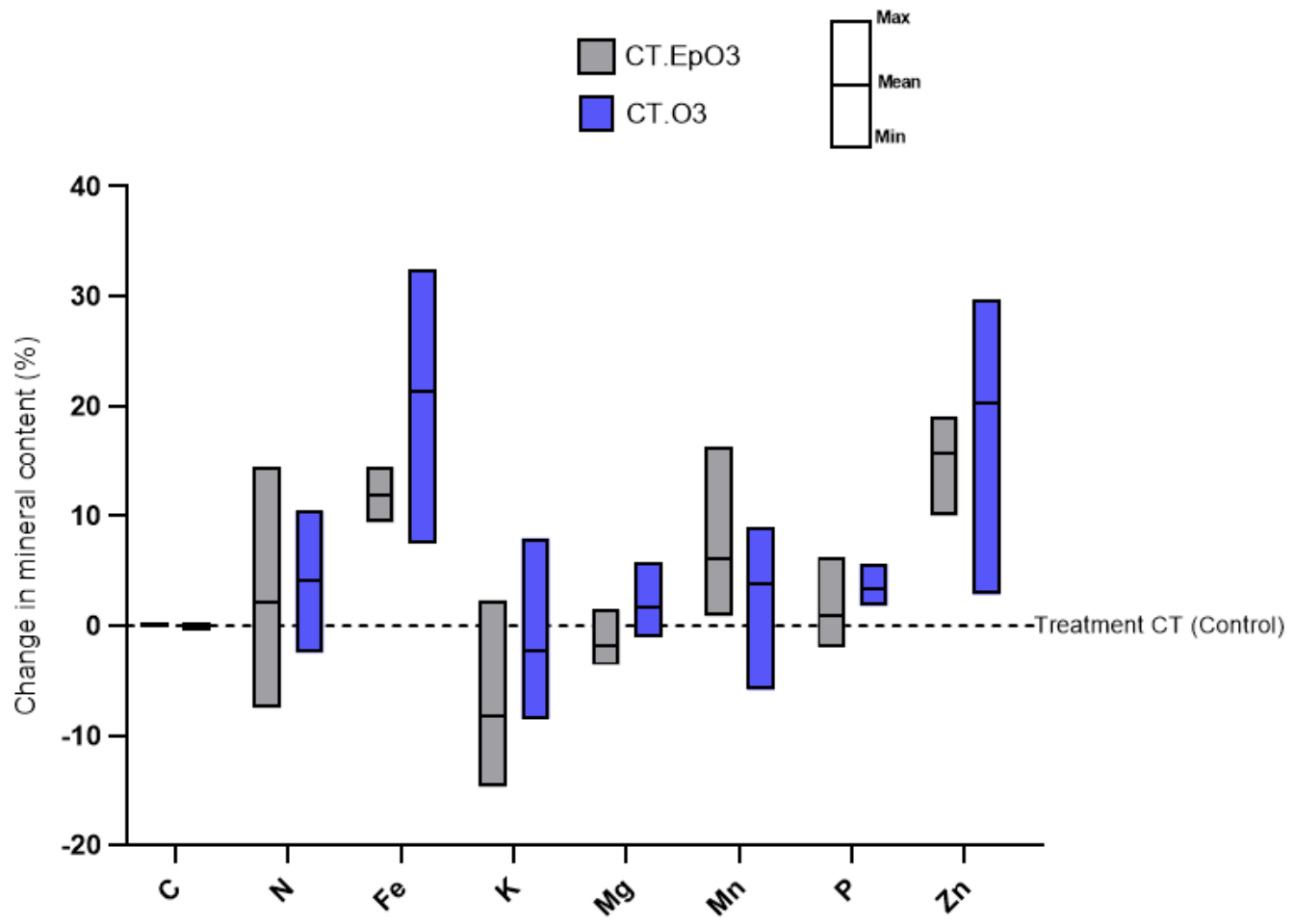

Figure 3

Change of mineral content of three European wheat varieties under combined effect of different ozone regimes in condition of high carbon dioxide and elevated temperature. CT = High CO2, higher temperature settings, and no 03 addition. CT.EpO3 = High CO2, higher temperature settings and episodic 03 addition. СТ.03 = High $\mathrm{CO} 2$, higher temperature settings and chronic 03 addition. 
A

B
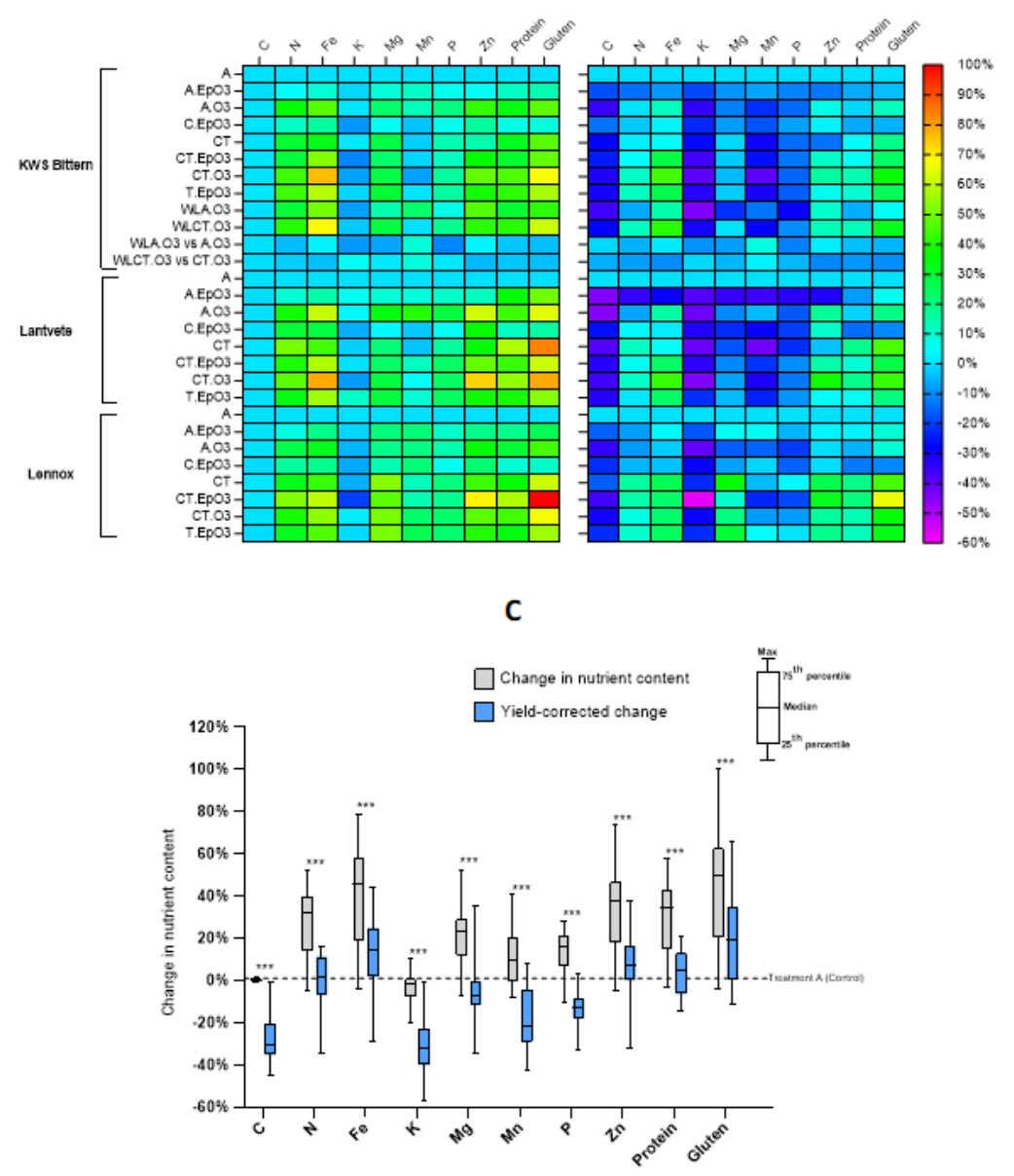

Figure 4

Changes in grain mineral content of three European wheat varieties under climate change treatments before (A) and after (B) yield correction, and overall comparison of effect on each nutrient (C). A = Ambient CO2, lower temperature settings and no 03 addition (control). A.Ep03 = Ambient CO2, lower temperature settings and episodic 03 addition. A. 03 = Ambient CO2, lower temperature settings and chronic 03 addition. C.EpO3 = High $\mathrm{CO} 2$, lower temperature settings and episodic 03 addition. $\mathrm{CT}=\mathrm{High} \mathrm{CO} 2$, higher temperature settings, and no 03 addition. CT.EpO3 = High $\mathrm{CO} 2$, higher temperature settings and episodic 03 addition. CT.O3 = High CO2, higher temperature settings and chronic 03 addition. T.EpO3 = Ambient $\mathrm{CO} 2$, higher temperature and episodic 03 addition. WLA.03: Ambient CO2, lower temperature settings and chronic 03 addition (i.e., A.03), in water-limited condition. WLCT.03 = High CO2,

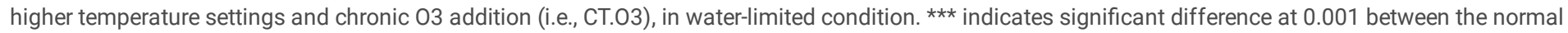
and the yield-corrected nutrient content, one-tailed pairwise Student's t-Test. 


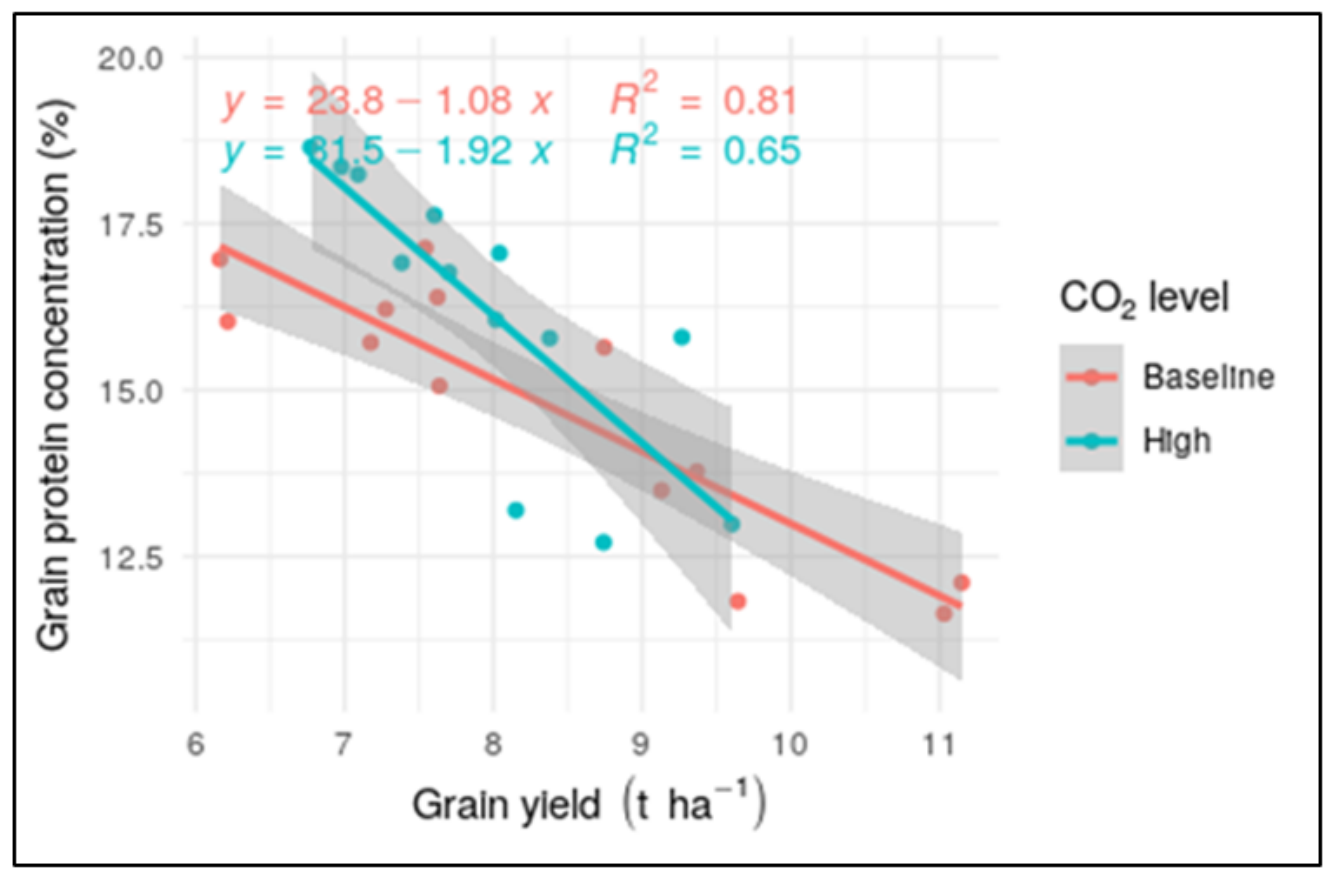

Figure 5

Relationship between grain yield and protein content for spring wheat varieties KWS Bittern, Lennox and Lantvete grown under baseline C02 (400 ppm; red points) and high $\mathrm{CO} 2$ level (700 ppm; blue points). Solid red and blue lines are linear regressions fitted against the red and blue points respectively and grey areas are $95 \%$ confidence intervals.
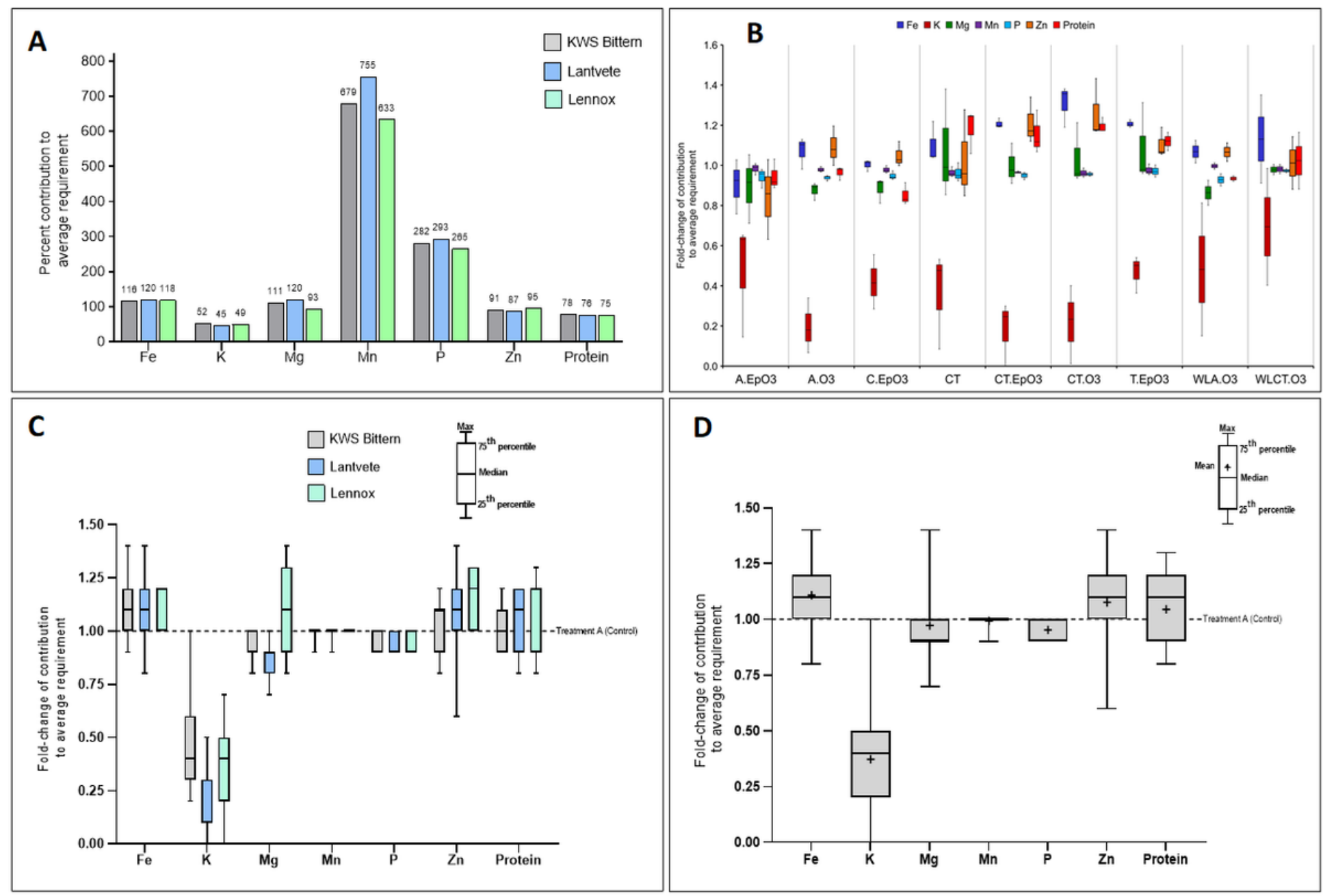

Figure 6 
Contribution of wheat raw whole flour consumption of $298.5 \mathrm{~g} /$ person/day to daily average requirement of some essential nutrients of European adults ( $\geq 18$ years): for 3 spring wheat varieties (A), effect of climate change treatments (B), effect of treatments on each variety (C) and overall effect of climate change factors on each nutrient (D). A = Ambient CO2, lower temperature settings and no 03 addition (control). A.EpO3 = Ambient CO2, lower temperature settings and episodic 03 addition. A.03 = Ambient CO2, lower temperature settings and chronic 03 addition. C.EpO3 = High $\mathrm{CO} 2$, lower temperature settings and episodic 03 addition. $\mathrm{CT}=$ High CO2, higher temperature settings, and no 03 addition. $\mathrm{CT}$.EpO3 = High $\mathrm{CO} 2$, higher temperature settings and episodic 03 addition. $\mathrm{CT} .03=\mathrm{High} \mathrm{CO2}$, higher temperature settings and chronic 03 addition. $\mathrm{T}$.EpO3 = Ambient $\mathrm{CO} 2$, higher temperature and episodic 03 addition . WLA.03: Ambient CO2, lower temperature settings and chronic 03 addition (i.e., A.03), in water-limited condition. WLCT.O3 = High CO2, higher temperature settings and chronic 03 addition (i.e., CT.03), in water-limited condition. $* \star \star$ indicates significant difference at 0.001 between the normal and the yieldcorrected nutrient content, one-tailed pairwise Student's t-Test.

\section{Supplementary Files}

This is a list of supplementary files associated with this preprint. Click to download.

- SuppMatFigureseffectCO2Temp03WLwheatnutrientcontent.docx

- SupplementaryMaterialTable1.xlsx 